$$
\begin{aligned}
& \text { Dossiê de } \\
& \text { Entrevistas: }
\end{aligned}
$$

Quatro décadas de independência 


\title{
Dossiê de entrevistas: quatro décadas de independência
}

\author{
Interviews Section: four decades of independence
}

\author{
Rejane Vecchia da Rocha e Silva \\ UBIRATÃ SOUZA *
}

* Docente do Departamento de Estudos Comparados de Literaturas de Língua Portuguesa da Faculdade Filosofia, Letras e Ciências Humanas da Universidade de São Paulo.

** Doutorando do Departamento de Estudos Comparados de Literaturas de Língua Portuguesa da Faculdade Filosofia, Letras e Ciências Humanas da Universidade de São Paulo. 
ano de 2015 registra uma data com dupla importância. A data se refere às exatas quatro décadas de independência de Angola, Moçambique, São Tomé e Príncipe e Cabo Verde. A dupla importância se refere ao fato de, por um lado, essa data marcar o golpe mais substancial às configurações imperialistas de Portugal no mundo, e, por outro, encerrar um processo de emancipação política que varria o continente africano desde a independência do Gana em 1957. Com efeito, com exceção dos casos da Namíbia, do Saara Ocidental e do Sudão do Sul, cujas independências precisaram ou precisam ocorrer a partir de dominações internas do continente, depois de 1975, ao menos na forma do estatuto político, nenhuma potência europeia dominava mais algum território em África.

A data exige reflexão por parte dos cientistas humanos. Como avaliar essas quatro décadas de consolidação da "África dos Estados", na acertada expressão de Elikia M'Bokolo? (2011: África Negra: História e Civilizações, Tomo II, p. 649) Sabemos que o surgimento de uma consciência emancipatória em África foi acompanhado de uma tomada de consciência em todo mundo colonizado, que conseguiu jogar luzes sobre o quanto exploratório e desumano foi o colonialismo ligado ao imperialismo (nas suas diferentes formas de ocupação) a partir do século XIX. Esse processo teve em seu bojo a avidez de despir as ciências humanas dos latentes traços imperialistas que lhe caracterizaram desde suas formações no século XIX e XX, e, neste sentido, todas as áreas do conhecimento humano foram afetadas: a antropologia, a história, a linguística, os estudos literários, a geografia, todas essas ciências, hoje, podem receber o epíteto "colonial", quando nos referimos à sua prática em certo período da história. Esse processo de nudez do caráter imperialista das ciências humanas pode hoje ser chamado, a propósito, de "descolonização dos saberes". Ora, se um processo científico de tamanha monta, a descolonização dos saberes, se desenvolve em paralelo a um processo político de igual tamanho, a emancipação política do mundo colonial, com tamanhas e evidentes imbricações, que efeitos haverá sobre as ciências humanas essas quatro décadas de independência política e de descolonização prática dos saberes?

Quer dizer, inúmeros institutos, centros de pesquisa, departamentos, programas de pós-graduação, de inúmeras universidades do mundo se empenharam com afinco em descolonizar os saberes, e isso estabeleceu muita relação com os processos políticos em curso nos países de África, da Ásia, da Oceania e até mesmo das Américas. Passados os processos políticos, e buscadas as descoloniza- 
ções, o quão descolonizados estamos? O quanto as ciências caminharam neste sentido, e o quanto deixou de caminhar? Mesmo fora das ciências, e pensando nas políticas dos Estados independentes, aqueles objetivos propostos quando as independências urgiram em programas efetivos se mostraram viáveis durante o tempo, foram cumpridos, foram traídos ou abandonados? Em suma, qual o saldo, dentro e fora das ciências, que é possível fazer de quatro décadas de independência e dos Estados em África?

Para que essa discussão ganhasse corpo, a Revista Via Atlântica convocou alguns nomes para compor um Dossiê de Entrevistas. O primeiro nome é a Profa. Dra. Leila Leite Hernandez, professora livre docente do departamento de História da Faculdade de Filosofia, Letras e Ciências Humanas da Universidade de São Paulo. A Profa. Dra. Leila é a primeira professora de um curso de História da África como disciplina obrigatória em um bacharelado em História no Brasil, e uma das vozes mais qualificadas para tratar do assunto na atualidade. É autora de três livros fundamentais para os estudos da História do continente: Os filhos da terra do sol: formação do Estado-nação em Cabo Verde (São Paulo: Selo Negro, 2002); A África na sala de aula: visita à história contemporânea (São Paulo: Selo Negro, 2005); Memória e História: Administração para o Desenvolvimento. (Praia, Cabo Verde: Secretaria do Estado da Administração Pública, 2011). Em 2013, foi agraciada com a outorga do Grau de Oficial pelo Conselho da Ordem de Rio Branco, Ministério das Relações Exteriores. A Profa. Leila é convidada a discutir questões mais teóricas relativas às independências e às configurações dos Estados-nações em África, bem como tratar de assuntos como a descolonização dos saberes. Perguntamos também a Profa. Leila a respeito do futuro das ciências humanas acerca de África, e de como seria possível descolonizar as mentes fora das ciências, no âmbito do senso comum, em que o racismo e o saber etnocêntrico parecem sobreviver com toda a força. A entrevista com a Profa. Leila foi realizada por Ubiratã Souza, doutorando no Programa de Pós-Graduação em Estudos Comparados de Literaturas de Língua Portuguesa, na Faculdade de Filosofia, Letras e Ciências Humanas da Universidade de São Paulo.

As duas outras entrevistas que se seguem apresentam o caráter depoimental de testemunhas vivas dos processos históricos a que nos referimos. A primeira delas se refere ao cineasta moçambicano Camilo de Sousa. Sobrinho da poetisa moçambicana Noémia de Sousa, Camilo estava na Mafalala, na periferia da antiga Lourenço Marques quando o colonialismo português em Moçambique 
atingia seu ponto mais conflituoso e insustentável, e, ainda jovem, foge como refugiado político para a Bélgica. Desde a Europa faz contato com a nascente Frente de Libertação de Moçambique, e pega em armas para defender a emancipação política de seu país. Com a independência conquistada, Camilo de Sousa se transforma num agente cultural de Moçambique, integrando o recém-criado Instituto Nacional de Cinema, e tomando parte na criação de uma arte cinematográfica no país. Produz diversos filmes documentais que retratavam a criação de um Estado moçambicano, participou e dirigiu o conhecido Kuxa Kanema, revista cinematográfica semanal que tinha por objetivo informar as populações mais remotas dos feitos do novo governo. Após os anos de 1990, Camilo passa a atuar em instituições independentes de produção cinematográfica, como a Coopimagem, e, posteriormente, a Ébano Multimedia. O testemunho de Camilo é fundamental para descortinarmos o pensamento de uma geração que cresceu sob a opressão colonial portuguesa, pegou em armas para defender um projeto, doou a vida toda com empenho a um ideal de país, e viu o "sonho desmoronar", como o próprio cineasta afirma. Após as liberalizações da economia e constituição de um capitalismo intensivo e neoliberal em Moçambique, o depoimento de Camilo demonstra os caminhos árduos para a sobrevivência de um trabalhador independente da cultura naquele país.

O segundo depoimento testemunhal de nosso Dossiê é da também cineasta moçambicana Isabel de Noronha. Isabel tinha dez anos quando ocorreu a independência de Moçambique, e cresceu dentro da lógica de construção de um país calcado numa revolução socialista. A geração imediatamente anterior à sua, à qual pertencia Camilo de Sousa, foi o exemplo em que as novas gerações se miravam. Isabel pertenceu às dinâmicas culturais dos grupos que se reuniam na Associação dos Escritores Moçambicanos, e que se empenharam em construir um projeto em torno das artes e culturas moçambicanas. Isabel entrou no Instituto Nacional de Cinema em 1984 e, assim, passou a cobrir e documentar a guerra pós-independência. Seu testemunho destaca, sobretudo, as inúmeras fraturas sociais que se seguiram à construção do Estado, os dilemas e os impasses em que Moçambique mergulhou e mergulha até hoje. Em sua entrevista, Isabel tem oportunidade de refletir acerca do meio cultural moçambicano hoje, das dificuldades em se produzir um cinema voltado para "dentro" e de como essas questões estão totalmente relacionadas à escassez de uma política cultural de Estado, não só em Moçambique, mas em outras localidades do mundo 
pós-imperial. As entrevistas com Camilo de Sousa e Isabel de Noronha foram realizadas pela Profa. Dra. Rejane Vecchia da Rocha e Silva, professora de Literaturas Africanas de Língua Portuguesa da Universidade de São Paulo, e por Ubiratã Souza, doutorando no Programa de Pós-Graduação em Estudos Comparados de Literaturas de Língua Portuguesa, na Faculdade de Filosofia, Letras e Ciências Humanas da Universidade de São Paulo.

A quarta entrevista a compor o nosso Dossiê é com o renomado historiador congolês Elikia M'Bokolo. M'Bokolo é historiador e Directeur d'Études na École des Hautes Études en Sciences Sociales, Membro do Comité de redação dos Cahiers d'études africaines e Produtor na Radio France Internationale de Mémoire d'un Continent, emissão semanal de História da África. O seu principal tema de investigação é a História moderna e contemporânea da África. O enfoque é colocado na evolução e nas transformações políticas, em relação estreita com os processos intelectuais, culturais e sociais. Mais do que as peripécias do tempo presente e a sua interpretação, interessa-Ihe compreender o conjunto dos fenômenos de longa duração - permanências e recorrências, rupturas e inovações, captações e reapropriações - na sua interação com as dinâmicas contemporâneas. Elikia M'Bokolo tem publicado no Brasil o manual África Negra: história e civilizações, v. 1 e 2 (São Paulo: Casa das Áfricas / Salvador: EDUFBA, 2009), uma referência nos estudos de África e da diáspora negra em nosso país. Sua entrevista foi realizada por Cláudio Fortuna, do Centro de Estudos e Investigação Cientifica da Universidade Católica de Angola, Licenciado em Antropologia, Assistente de Investigação do referido Centro no Departamento de Estudos Sociais.

Ao justapor os dois depoimentos às duas entrevistas com caráter mais acadêmico, tem-se por objetivo recobrir um panorama crítico de origens diversas sobre como podemos olhar a África dos Estados, e os Estados independentes à distância de quatro décadas de finalização desse intenso processo. Os depoimentos decerto revelarão o quanto as dinâmicas históricas interferiram nas constituições daqueles sujeitos, em suas escolhas pessoais, nas suas visões sobre o futuro, na própria subjetividade, enfim, de cada uma daquelas pessoas que viveram naquele período. As análises acadêmicas que propusemos aos nossos professores decerto iluminarão os impasses, silêncios, ausências e dúvidas por que passam as ciências humanas quando abordam a complexidade e a variedade do continente africano. 


\section{LEILA LEITE HERNANDEZ}

IA ATLÂNTICA: O filósofo e antropólogo moçambicano Severino Ngoenha, num texto seu de 1998, reflete a respeito do que chama de "mecanismos exógenos de integração nacional", considerando a exogenia desses mecanismos como um complicador a mais nos já complexos processos de construção nacional, de identidade e de construção do Estado em Moçambique. Já ao largo de algumas décadas das independências africanas, muito se tem dito a respeito dos impasses gerados entre os projetos de modernidade e de desenvolvimento propostos pelas elites africanas, e seu considerado "fracasso" em criar condições mais favoráveis e melhorias efetivas para a população. Na maioria das vezes, a percepção desses "fracassos" enfatiza o quanto esses projetos de modernidades são exteriores às formas de desenvolvimento produzidos no interior das diversas culturas que tanto os nacionalismos quanto os Estados nacionais precisariam integrar, mas que, na maioria das vezes, apresentaram feições bastante excludentes e negligentes em relação às outras formas de episteme, cognição e gestão comunitárias possíveis em seus respectivos contextos. Exogenia e endogenia, exclusão e integração, Estado e nação: refletir a respeito desses temas é refletir, sobretudo, a respeito da itinerância de ideias e de estruturas de pensamento que viajam e são apropriadas de forma criativa ou não em diferentes contextos, mas que, comumente, geram discussões e embates. De que forma a Sra. analisa essa discussão? A partir especialmente de sua obra e de seu pensamento acadêmico, quais os resultados mais relevantes que a Sra. julga ter obtido ao adotar uma abordagem histórica para pensar os contextos africanos do pós-independência?

LEILA HERNANDEZ: Desde os anos de 1960 a experiência do impropriamente chamado "Terceiro Mundo" - ou seja, os países do Sul - faz pensar, sobretudo na chave dos marxismos, as relações entre os países subdesenvolvidos e dependentes com o chamado "Primeiro Mundo" e as particularidades sociais e culturais que garantiriam o desenvolvimento futuro. Cabe destacar que a partir destes pontos foram levantadas questões de estratégia política concreta, assim como da própria teoria marxista, em uma conjuntura em que se fazem heterodoxa e plural, acarretando uma diferenciação muito tênue do que era ser um país de política marxista. Pragmaticamente, é sabido que as várias abordagens 
apresentaram fortes divergências ao lado de convergências, de vez que a política daqueles anos condicionava o sentido da reinterpretação histórica. O significativo ponto de convergência girava em torno da aposta que seria muito difícil que a descolonização política em si mudasse as relações econômicas entre os países recém-independentes que integraram os antigos impérios europeus o que, no caso dos países africanos de língua oficial portuguesa, se daria só em meados da década seguinte. Estas relações, marcadas por dependências políticas e militares e a uma economia atrelada às antigas metrópoles, levaram a invenção do termo "neocolonialismo", referindo-se aos entrelaçamentos de forças externas com as internas, adjetivando as independências como formais. Esta situação pós-independências se caracterizou, por exemplo, por acordos de defesa colonial da França com estados africanos, alguns negociados antes das independências como com a República Centro Africana, o Congo, o Gabão, o Chade, a Federação do Mali e Madagáscar. Ganhou clareza o fato de que as independências não promoveram rupturas com a organização das sociedades herdadas e a estrutura política e administrativa, como o sistema econômico-social, não foram destruídos, gerando o subdesenvolvimento e os entraves ao "progresso".

Estes aspectos levaram a sucessivos debates, discussões e a posições políticas diferentes entre as lideranças econômicas, políticas e intelectuais dos países africanos acerca da necessidade urgente de identificar as raízes e os elementos condicionadores do subdesenvolvimento para que elaborassem projetos eficientes, bem como as escolhas para que se tornassem efetivos. Esse foi o sentido de encontros para identificar e compreender as crises nos países africanos, culminando na Conferência dos Ministros dos Negócios Estrangeiros e do Plano Africanos, realizada nos dias 30 e 31 de março de 1980, em Adis-Abeba, e apresentados na 13a Sessão Extraordinária da Assembleia Geral da ONU.

Nesses encontros, fugindo da vitimização e voltados para soluções rápidas e eficazes, políticos e intelectuais africanos deram ênfase aos fatores endógenos do subdesenvolvimento para depois articular os exógenos, como a recessão da economia mundial; a baixa contínua dos preços das matérias primas; e o reforço das políticas protecionistas dos países desenvolvidos. Acrescente-se que em 1985, a África tinha uma dívida pouco maior que a metade daquela da América Latina, o que pesava mais nas economias africanas por terem capacidade de exportação menor que o seu PIB.

É sabido que este é um tema vasto e multifacetado, todavia penso que estão 
registrados os principais pontos analisados, aos quais merece destaque os diferentes interesses e as várias perspectivas político-ideológicas perceptíveis, na própria criação da Organização da Unidade Africana, em 1961, não raro acirrados nas décadas subsequentes.

Estes são temas que não podem ser relativizados, uma vez que fizeram parte de processos históricos, da mesma forma que as dicotomias como tradicional/ moderno, cidade/campo, desenvolvimento/subdesenvolvimento integraram os pensamentos das elites africanas. A necessidade de ruptura destas dicotomias surgiria com ênfase, quase 40 anos depois das independências por africanistas - africanos ou não - que passaram a repensar a "descolonização das mentes", conforme expressão consagrada já nos anos de 1960.

Quanto ao meu trabalho como docente e pesquisadora tem tido como objetivo compartilhar as teorias pós-coloniais como propostas por Edward Said e Mary Louise Pratt, por exemplo, e mais recentemente, pelas obras de Appiah, Achille Mbembe, Hountondji, Mudimbe, Elungu e outros que em diferentes registros pensam os entraves e os caminhos para pensar rupturas com a estrutura discursiva da razão ocidental. Considero que estas preocupações estão presentes, sobretudo, em minhas escrituras mais recentes, nos meus cursos de graduação e pós-graduação no Departamento de História da FFLCH/USP, no grupo de Estudos que coordeno e em minhas pesquisas.

V. A.: Ainda pensando na funcionalidade da história para pensar a política africana, acontecimentos das últimas décadas fizeram aumentar o debate acerca da representatividade e das condições de efetivação da democracia no continente africano. Casos emblemáticos como a Guiné Equatorial, o Zimbábue e Angola, em que um mesmo governante ocupa essa posição há décadas, fazem muitos observadores questionar a validade e a legitimidade da democracia nesses países. Ocorre que, na maioria das vezes, esses observadores, e me refiro especialmente aos grandes veículos de comunicação do ocidente, partem de pressupostos bastante etnocêntricos para pensar essa questão, sobretudo considerando o modelo de democracia estadunidense como válido e necessário para quaisquer ambientes. Outrossim, o constante alarde a respeito das fraudes eleitorais, $e$ práticas de autoritarismo e centralismo fragilizam os próprios discursos oficiais a respeito da configuração política desses Estados. Como, a partir da abordagem da história, podemos tornar esse debate mais dialético, considerando as linhas 
de força que exercem poder sobre essas configurações políticas? Ou ainda, qual é o limite do relativismo: até que ponto devemos questionar o modelo de democracia relacionando-o com os modelos ocidentais e até que ponto devemos estar atentos às novas possibilidades de configurações desses modelos?

L.H.: Ao retomar as críticas feitas por intelectuais da estatura de Edem Kodjo, podemos constatar o descontentamento com as independências. Para Kodjo as independências levaram os países africanos a constituírem Proto-Nações, cujas características permitiram configurar um "despotismo obscuro", no qual é possível perceber os seguintes traços: o poder não emanava da soberania popular; a existência de um partido único; a ausência de contra poderes nos domínios políticos, sociais, econômicos e culturais; a centralidade do papel das forças armadas e paramilitares; e a manutenção de estados não viáveis, comandados pela coerção e pela violência. Kodjo também definia o Estado como passível de ser traduzido como providencialista e autocrático, além de estatizante. Com as referidas características, este Estado acabou por ser centralizador ao ponto de cercear a liberdade de expressão e não hesitar em recorrer à violência física e simbólica em nome do surgimento de um "homem novo" adequado ao desenvolvimento, ao progresso e à modernidade, nos padrões ocidentais eurocêntricos e norte-americanos, em nome da "legitimidade histórica" e da manutenção da unidade da Nação encobrindo, não raro, as razões de instabilidades políticas, conflitos sociais e guerras internas.

Entretanto, é importante considerar que uma grande parte dos intelectuais africanos tem destacado o caráter plural e a heterogeneidade das sociedades, com diversas componentes étnicas; as diversas classes sociais em formação; as relações de poder entre etnia, classe e massa; e a falta de consciência nacional. Esta situação é potencializada pela grande desigualdade na distribuição de rendimentos e pela extrema pobreza.

Nos dois ou três últimos anos de 1980 sobrepuseram-se as imposições do Fundo Monetário Internacional (FMI), condicionando financiamentos à abertura de uma economia de mercado e à efetivação de reformas políticas em nome da democracia e da cidadania nos moldes ocidentais. Em sentido diametralmente oposto, isto era familiar às elites africanas desde o final da I Guerra Mundial e reforçado no imediato pós II Guerra Mundial, como atestam as resoluções do V Congresso Pan-africano (1945), cuja Resolução Final proclamava a imperiosa necessidade de dar um basta ao imperialismo, ao capitalismo, ao colonialismo e 
ao racismo. E quase uma década depois, a Conferência de Bandung afirmava as condições para as soberanias interna e externa dos Estados e reforçava a importância dos Direitos Humanos, estendendo-os às nações, além de proclamar uma política de não alinhamento.

Claro está que as reivindicações dos anos cinquenta e sessenta foram no sentido de alcançar as independências e com este objetivo se uniram a despeito de suas posições políticas com diversos matizes ideológicos, enquanto no final dos anos oitenta se individualizaram, acentuando suas relações de dependência dos países africanos, no quadro do sistema capitalista. É evidente que precisamos ser críticos em relação a este conjunto de circunstâncias, assim como às dinâmicas culturais - no sentido alargado do termo - que ensaiam novas experiências de natureza oposta aos modelos impostos e aceitos pelas elites à frente dos Estados africanos, como tem o corrido, por exemplo, no Quênia e na Libéria.

V. A.: Um dos principais objetivos dos estudos de História acerca de África tem sido a criação efetiva de um processo que poderíamos chamar de "descolonização dos saberes", ou seja, produzir um conhecimento sobre África que consiga, a um tempo, realocar a posição europeia diante dos antigos espaços imperiais e considerar as linhas de força coloniais e imperialistas que tangenciaram as ciências sociais, biológicas e do conhecimento a partir dos finais do séc. XVIII, por todo o séc. XIX e, a bem da verdade, até os nossos dias. Essa discussão aglomerou uma grande quantidade de pensadores africanos e de outras latitudes do mundo pós-imperial, que, cada um ao seu modo, pensou sua condição dentro de diversas chaves específicas: alguns mais materialistas, outros mais filosóficos, enfim. Lembro-me perfeitamente da Sra. se referir a esse objetivo de "descolonizar os saberes" como uma missão imperiosa, que devemos perseguir com avidez até nos momentos mais singelos da nossa trajetória acadêmica, buscando atentar para os pequenos cadafalsos que nossa formação etnocêntrica nos propicia a cada segundo. A que estágio a Sra. julga que estamos dessa batalha? Aqui, já bem entrados no séc. XXI, julga que avançamos quanto dessa missão, e o quão descolonizados estão os saberes, se isso é possível de ser mensurado? Como percebe essa descolonização no âmbito do senso comum e das culturas de massas? o que esperar do futuro nesse sentido?

L.H.: A descolonização dos saberes - em particular das Ciências Humanas - requer a compreensão dos modelos epistemológicos gestados na segunda metade 
do século XVIII, hierarquizando e classificando os homens a partir de características biologistas atreladas às características morais e as atribuições intelectuais. Com isto, os africanos foram naturalizados enquanto seres sem povo, nação, estado, religião, escrita e, assim, primitivos incapazes de transformar a natureza em cultura, logo, considerados povos sem História. Importante também é ressaltar que houve até cerca de dez ou vinte anos o reinado das homogeneidades relativas aos impérios, às colônias e aos africanos, posição contraposta pelo reconhecimento de heterogeneidades o que, em relação às histórias dos africanos permite identificar e compreender as resistências, mas também as conexões, sem, no entanto, encobrir as violências e os racismos.

Ora, estes aspectos foram suficientes para justificar ideologicamente o imperialismo gnosiológico e o imperialismo político, e a combinação entre ambos. Estas justificativas ideológicas dizem respeito ao estatuto ocidental dos saberes sobre o homem e a sociedade, esta, uma questão acadêmica, assim como política e intelectual. De outra parte há de ter claro que são as práticas coloniais que informam o discurso imperial, se fazendo presentes na invenção das representações de África e dos africanos, as quais têm um impacto político nas sociedades europeias e, em igual medida, nas coloniais.

Ora, estes saberes e práticas coloniais têm de ser desaprendidas, dando lugar a uma reestruturação das relações que se estabeleça entre conhecimento e poder no âmbito de uma perspectiva libertária, como propõe Edward Said. É como tenho tentado compreender as questões da situação colonial, caminhando a passos lentos por conta da complexidade dos processos históricos, sempre atenta às armadilhas do etnocentrismo. Procuro salientar o afastamento - longe do abandono - das culturas dos povos locais, as quais tem sobrevivido. Cabe-nos estar atentos à criação do mundo de cada povo sobre os destroços e a recriação permanente, porquanto histórica, de sua cultura plural e diversa. Por fim, há de acrescentar que estes saberes estão sendo descolonizados de forma mais lenta do que gostaríamos, mas tem se feito muito, sobretudo nos últimos trinta e cinco, quarenta anos, por africanistas africanos ou não.

Já no âmbito do senso comum e da cultura de massas as representações são hegemônicas e os processos de mudança têm sido muito mais lentos. Ainda há uma forte presença de preconceitos e de lacunas de conhecimento. Os diferentes órgãos de imprensa, a filmografia, a permanência dos provérbios, cantigas de trabalho, letras de música e a própria socialização das crianças - destacando- 
-se a escolaridade formal - a literatura colonial, as feiras coloniais e as exposições universais reforçam, das formas mais variadas, os padrões universais de Humanidade que, paradoxalmente, incluem o racismo moderno. Neste âmbito, o imaginário colonizado se entranha em um cosmopolitismo encobridor do provincianismo, sua verdadeira faceta e o processo de ruptura com as representações derivadas da estrutura discursiva do racionalismo ocidental tem apresentado uma significativa lentidão.

Alimento a esperança de que se afirmarmos e reafirmarmos o compromisso que reitero intelectual e político, de questionar e promover fissuras no pensamento ocidental, colaborando para que possamos chegar à ruptura da episteme e dos paradigmas caros ao colonial e às colonialidades nas sociedades que ainda guardam os modelos, padrões e valores próprios do imperialismo capitalista colonial. E ganharemos em compressão relativa ao pós-independência de países com regimes centralizadores e de partidos únicos que, desde a segunda metade dos anos de 1980, fizeram uma inflexão para uma economia de mercado e se transmutaram em democráticos sobre a égide do neoliberalismo. Por outro lado, poderemos colocar em cheque as representações que caracterizam o imaginário colonizado das ex-colônias e das ex-metrópoles.

V. A.: De alguma forma completando a questão anterior, somos frequentemente interpelados nas mais diversas situações da vida acadêmica e da vida comum por estudarmos outras realidades diferentes da brasileira. Em se tratando de África, parece que subsiste ainda certa "crise" para pesquisadores brasileiros, que são frequentemente assediados sobre o quão "inseridos" podemos estar ou não naqueles contextos, tão próximos do nosso em alguns aspectos, mas, em muitos outros, tão diferentes. Por fim, como a Sra. julga ser a postura do pesquisador brasileiro diante da África? Quais as vantagens que temos justamente por assumirmos essa postura, e quais os limites disso? Como essas tensões se equacionaram ou não na sua trajetória acadêmica?

L.H.: A opção por estudar África é um constante desafio, a começar pelo fato de que as academias brasileiras estão impregnadas da episteme ocidental, tanto europeia como norte-americana. Isto está presente nas grades curriculares e na tardia obrigatoriedade para a inclusão dos Estudos Africanos e dos afro-brasileiros nas grades curriculares, o que na FFLCH /USP ocorreu em 1998 e, pelo que sabemos, foi o primeiro curso de História da África como disciplina obrigatória 
em um bacharelado em História. Tive a honra e o grande prazer de ministrar a disciplina desde então.

De outra parte há uma importante tradição em estudos sobre o tráfico Atlântico e a escravidão e, mais recentemente, acerca das culturas diaspóricas das Américas. Há cerca de dezessete anos atrás quando História da África começou a integrar a grade curricular do Bacharelado em História havia professores do Departamento com a expectativa que meu trabalho teria de ser uma disciplina auxiliar da História da escravidão; outros sugeriram que eu desse um programa voltado para Angola, um dos Países de Língua Oficial Portuguesa, não por acaso, com vários portos de trato de homens feitos escravos.

Não foi fácil resistir e defender a necessidade de pensar uma História em que a África fosse concebida como um continente caracterizado por heterogeneidades, repleto de dinamismos e especificidades. Um continente articulado aos demais, o que torna mais relevante o seu papel na História Universal. O desafio que propus e que se renova a cada aula é imenso e o esforço enorme, mas acredito que - ainda admitindo falhas - o esforço tem valido a pena.

Hoje acredito que dificuldades e percalços têm negatividades possíveis de se reverter em positividades, acabando por se constituir em instigantes desafios para produzirmos com vistas a alcançar qualidade cada vez maior. Levaram-me ainda a procurar novos caminhos de inserção entre pesquisadores daqui do Brasil como de outros países, sobretudo de África e da Europa. Na minha trajetória nem tudo foi alcançado, mas cheguei muito além do que sonhei um dia. Tenho três livros sobre África que são referência no Brasil e que colaboraram de forma definitiva para que a História da África entrasse nas salas de aula; fazem parte de bibliografias obrigatórias em disciplinas de graduação e de pós-graduação; integram a bibliografia de inúmeras dissertações de Mestrado e, teses de Doutoramento e artigos e livros de investigadores no Brasil e em vários países da África e da Europa. Têm sido alvo de resenhas em África (como em Nigéria) e na Europa (França e Portugal). Tenho participado de eventos internacionais, o mais recente, em Lisboa, na Fundação Calouste Gulbenkian Museu Gulbenkian, ao lado de pesquisadores reconhecidos internacionalmente, da Inglaterra, França, Bélgica, Estados Unidos, Moçambique e Angola. E mais do que tudo, tenho tido agradabilíssimas surpresas com a maior parte dos meus alunos e orientandos, que têm me dado muitas alegrias pela qualidade dos seus trabalhos de Mestrado e Doutorado e em pouquíssimo tempo tem se tornado professores concursados 
em universidades brasileiras. $\mathrm{O}$ mesmo tem se passado com alunos africanos que vieram ser meus orientandos pelo Programa PEC-PG/CAPES que retornam aos seus países e não tardam a ingressar na carreira acadêmica como docentes e pesquisadores.

V. A.: As literaturas dos países africanos de língua oficial portuguesa parecem ter se desenvolvido até os nossos dias, senão com uma obsessão para o diálogo com a História, pelo menos criando ensejos muito vívidos para pesquisas que assumam um caráter interdisciplinar. Situando-se, na maioria das vezes, nas fraturas sociais, no campo do embate e da subversão, seja no período colonial, quando questionavam e denunciavam todo o contexto de exploração e violência física e simbólica, seja no pós-independência, questionando e denunciando os alcances e os limites dos Estados nacionais, os textos parecem sempre apontar para uma reflexão sobre o fenômeno humano como um todo, desde a organização da linguagem até a organização das sociedades. Como avalia essas características das literaturas africanas de língua portuguesa do ponto de vista da História? Como avalia a produção acadêmica que tem se esforçado para enfatizar esses laços entre História e literatura ou vice-e-versa?

L.H.: Desde o século XIX a imprensa e a literatura têm ocupado um lugar proeminente como veículo transmissor de ideias. No início continha reivindicações e no transcorrer do tempo deixa entrever a negação de aspectos do colonialismo, em especial, do racismo e das formas compulsórias de trabalho até chegar a uma total negação da situação colonial, desnudando suas formas de violência e o racismo, não raro, atrelado ao etnocentrismo. Nos anos da guerra de libertação e no pós-independência, a poesia de combate e o romance histórico fizeram o importante papel de reforçadores dos ideais dos movimentos de libertação, assim como mais tarde, de crítica aos excessos cometidos pelos Estados independentes.

Neste sentido, a imprensa e a literatura veicularam fatos e processos históricos fazendo, no caso da imprensa, o papel de partido político e no da literatura ganhando o espaço da história. Claro está que no caso da literatura é indiscutível sua relação com a história, o que pode ser encontrado nos principais romancistas como os angolanos Luandino e Pepetela e o moçambicano Mia Couto. Esta é uma das razões para que a literatura e a imprensa sejam investigadas enquanto fontes por muitos historiadores. Os diálogos entre Literatura e História (e vice 
em universidades brasileiras. O mesmo tem se passado com alunos africanos que vieram ser meus orientandos pelo Programa PEC-PG/CAPES que retornam aos seus países e não tardam a ingressar na carreira acadêmica como docentes e pesquisadores.

V. A.: As literaturas dos países africanos de língua oficial portuguesa parecem ter se desenvolvido até os nossos dias, senão com uma obsessão para o diálogo com a História, pelo menos criando ensejos muito vívidos para pesquisas que assumam um caráter interdisciplinar. Situando-se, na maioria das vezes, nas fraturas sociais, no campo do embate e da subversão, seja no período colonial, quando questionavam e denunciavam todo o contexto de exploração e violência física e simbólica, seja no pós-independência, questionando e denunciando os alcances e os limites dos Estados nacionais, os textos parecem sempre apontar para uma reflexão sobre o fenômeno humano como um todo, desde a organização da linguagem até a organização das sociedades. Como avalia essas características das literaturas africanas de língua portuguesa do ponto de vista da História? Como avalia a produção acadêmica que tem se esforçado para enfatizar esses laços entre História e literatura ou vice-e-versa?

L.H.: Desde o século XIX a imprensa e a literatura têm ocupado um lugar proeminente como veículo transmissor de ideias. No início continha reivindicações e no transcorrer do tempo deixa entrever a negação de aspectos do colonialismo, em especial, do racismo e das formas compulsórias de trabalho até chegar a uma total negação da situação colonial, desnudando suas formas de violência e o racismo, não raro, atrelado ao etnocentrismo. Nos anos da guerra de libertação e no pós-independência, a poesia de combate e o romance histórico fizeram o importante papel de reforçadores dos ideais dos movimentos de libertação, assim como mais tarde, de crítica aos excessos cometidos pelos Estados independentes.

Neste sentido, a imprensa e a literatura veicularam fatos e processos históricos fazendo, no caso da imprensa, o papel de partido político e no da literatura ganhando o espaço da história. Claro está que no caso da literatura é indiscutível sua relação com a história, o que pode ser encontrado nos principais romancistas como os angolanos Luandino e Pepetela e o moçambicano Mia Couto. Esta é 
uma das razões para que a literatura e a imprensa sejam investigadas enquanto fontes por muitos historiadores. Os diálogos entre Literatura e História (e vice-versa) tem se revelado bastante profícuos e devem ser incentivados e aprimorados. 


\section{CAMILO DE SOUSA}

IA ATLÂNTICA: O cinema moçambicano passa por dificuldades estruturais que não são exclusivas: grande parte do mundo de produção cultural sabe o quão dificultoso é angariar recursos para uma realização minimamente bem-feita. Essas dificuldades, no entanto, parecem ser mais patentes conforme se vai afastando dos grandes centros de poder do mundo, e vai chegando às periferias do mundo globalizado, como no Brasil ou Moçambique. A reflexão acerca da dificuldade econômica de existência de um cinema moçambicano ou brasileiro faz pensar a respeito do próprio estatuto da arte nesses espaços periféricos. A partir dessa reflexão, como foi que essas dificuldades se apresentaram em sua trajetória? Quais são os dissabores e os êxitos que permitem que você possa produzir a sua arte?

CAMILO DE SOUSA: Talvez fosse bom começar pelo aparecimento do cinema moçambicano, ou do cinema que é feito em Moçambique. Em 1975 quando foi criado o Instituto Nacional de Cinema, esta foi a primeira decisão, em prol da cultura, do governo acabado de sair da independência nacional. Nessa altura não havia quaisquer estruturas de produção de cinema. Havia, na realidade, umas produtoras portuguesas que produziam um Jornal da Actualidades (News Reel), e depois, em 1971 e 1972, apareceu outra produtora que fazia alguma coisa de ficção, mas de propaganda colonial. Mais tarde começou também a produção de cinema pornográfico, com uma produtora portuguesa, mas com o mercado voltado à África do Sul.

Então em Moçambique não havia, à altura da independência, tirando essas pequenas estruturas que eram um laboratório preto e branco, de $35 \mathrm{~mm}$, as câmeras eram aquelas velhas Arriflex. Então é criado o Instituto Nacional de Cinema em 1975, logo após a proclamação da Independência, e pôs-se aqui um dilema: como formar quadros moçambicanos para fazer cinema? Pois havia somente alguns técnicos assistentes de laboratório e assistentes de câmara, já que os portugueses não deixavam que os moçambicanos entrassem dentro deste métier. Então pôs-se um dilema para o Estado independente: compramos equipamentos e criamos aqui uma estrutura de cinema, mas, quem vai operar? Como vai ser? Vamos mandar vir pessoas de fora para virem fazer o nosso cinema? Ou 
vamos mandar moçambicanos para o estrangeiro para aprender (o que criava outro dilema: mas quando voltarem talvez já não se vão adaptar às condições estruturais ao país, ou simplesmente, não vão voltar)? Então se decidiu que o melhor era aprender fazendo. Mandar vir técnicos de fora e, ao mesmo tempo que vamos fazendo cinema, vamos aprendendo. Não haverá um vazio.

Foi isso que se fez e acho que foi uma das melhores coisas que aconteceu no país. Vieram cineastas e técnicos do Brasil, da Inglaterra, de França; vieram também do Canadá, de Cuba, da Mauritânia, da Etiópia e da Suécia. É, portanto, a partir desse momento que se começa a filmar. E cria-se então o Kuxa Kanema, como escola, para se poder chegar a outros voos. O Kuxa Kanema era um jornal cinematográfico de dez minutos semanais, uma vez que a televisão só aparece em Moçambique em 1983. Este jornal cinematográfico é criado, fundamentalmente para transmitir aos moçambicanos os ideais da Independência nacional, porque a Independência foi também um processo de aprendizagem, logo à partida. Primeiro, nós moçambicanos não nos conhecíamos entre nós, essa era a grande crise. Essa foi uma estratégia do Estado colonial para dividir os moçambicanos, dividir as etnias de forma que não houvesse qualquer contato entre elas, cumprindo assim a máxima do colonialismo: "dividir para reinar". Por conta disso, em 1975 éramos um país bastante dividido com muitas diferenças culturais e com uma barreira que eram as diferentes línguas faladas no país. Dizíamos que éramos todos moçambicanos, mas tínhamos muitas diferenças. O estado colonial português fez tudo para que houvesse lutas entre as diferentes nações. Então, era preciso passar essa ideia de que, apesar das diferenças, éramos todos iguais, todos moçambicanos, com costumes, hábitos e línguas diferentes, mas éramos todos moçambicanos. Na altura se falava de uma só nação, tentando esquecer o mosaico de culturas que era essa grande nação moçambicana.

E nesse sentido, o Kuxa Kanema era um veículo utilizado para mostrar aos moçambicanos quem eram os outros moçambicanos: mostrar aos do norte quem eram os do sul e do centro e por aí afora.... Era preciso dizer: "este também é moçambicano". E foi o Kuxa Kanema, que desempenhou um grande papel neste aspecto, a mostrar o que se fazia no sul, o que se fazia no norte. Divulgava inclusivamente alguns métodos de culturas agrícolas de alguns produtos que eram diferentes no norte e no sul, mas que depois as pessoas foram começando a utilizar. Inclusive alimentos que as pessoas não comiam por hábito, como a mandioca, que foi introduzida em certas partes de Moçambique só depois da 
Independência.

Depois começámos a trabalhar com documentário e ficção. Mas foi um cinema trilhado por aquelas pessoas que, bem ou mal, iam fazendo e iam aprendendo. E eu posso dizer que algumas pessoas do primeiro grupo que foram aprender no Instituto Nacional de Cinema vinham do desemprego. Isso correspondia a uma estratégia de criar cineastas que fossem filhos de operários e camponeses, dentro da lógica marxista-leninista. Formar cineastas que viessem do povo para criar a imagem que fosse do e para o povo. E foram crescendo ali dentro, com dificuldades, mas os resultados foram bons. Alguns ainda estão produzindo, como é o caso do Gabriel Mondlane, técnico de som e realizador, que tem filmes bem conseguidos.

Nos primeiros anos, até 1987, com o apoio total do Estado (o Estado obtinha receitas substanciais pois detinha o monopólio da distribuição e era proprietário da maioria das salas de cinema do país que haviam sido abandonadas pelos donos que saíram de Moçambique logo após a proclamação da Independência), o Instituto Nacional de Cinema possuía fundos para estúdios, equipamentos, materiais de laboratório, película, formação e dinheiro para produção. Foram os momentos áureos da produção de cinema. Estávamos com um nível de organização e de produção bastante bons para um país com poucos anos de independência e que tinha começado do zero.

Mas não é possível esquecer que existia uma expectativa de que o Kuxa Kanema cumprisse o objetivo de disseminação de uma mensagem política. Não há como negar que o Kuxa Kanema serviu para isso: para transmitir a mensagem da Independência e da unidade nacional; o que era, de facto a Independência e o que era um país independente, do ponto de vista político, econômico e das relações internacionais. Mas também serviu para transmitir mensagens do tipo de economia, do tipo do desenvolvimento que se pretendia aplicar no país. Então, fazíamos muitas filmagens nas fábricas, nas aldeias comunais, nas machambas estatais, nas escolas, no recém-constituído Serviço Nacional de Saúde. A ideia era mostrar o que se estava fazendo no país, o que era esse país que se construía todos os dias com a participação de todos. Por vezes, eu vejo isso referido como se fosse apenas propaganda política. A propaganda política existia, mas essa política refletia-se em coisas muitos concretas do quotidiano da construção do país e era o que o Kuxa Kanema mostrava. Então, não era só propaganda política, mas era todo um conceito do que seria uma nação, nas suas diferentes verten- 
tes, na prática do dia a dia. Depois começou a guerra; primeiro a guerra com a Rodésia, e depois a guerra com a RENAMO; aí, eram basicamente notícias sobre a guerra e o esforço que o país fazia para se sustentar em meio a uma guerra de desestabilização, não só em Moçambique, mas na região Austral de África.

Hoje podemos discutir se a mensagem que se passava correspondia de fato a tudo o que estava a ser feito. É evidente que não, que havia coisas que não se mostravam, não eram publicamente faladas. Por outro lado, lembro-me agora do meu primeiro filme como diretor - OFENSIVA, de 1980 - em que aparece o presidente Samora Machel a entrar nos locais de trabalho e a dizer: "há muita corrupção!" E a destruir completamente os esquemas de corrupção existentes. Isso era público, está filmado, ele fazia em praça pública. É claro que isso pode ser questionado em termos de violência psicológica. A pessoa ser acusada em frente à câmara, de não fazer aquilo que eram os seus deveres profissionais, prejudicando populações e, por conseguinte, o próprio país. Na altura, todos achávamos que era a forma de endireitar as coisas e impedir que os "sabotadores" da revolução pusessem o povo contra o seu próprio governo. Não há revolução que se faça sem "contras", sem aqueles que apenas querem dividir para impedir a construção do bem-estar de todo o povo. Mas também havia uma paranoia por parte do governo, do partido e de parte dos seus militantes: viam o "inimigo", os "contrarrevolucionários", os "reacionários" etc., em todo o lado; nos locais de trabalho, na rua, na sala de cinema, nos cafés, nos bares. Isso ajudou a que a revolução fosse enfraquecendo. As pessoas iam para as cadeias ou para os campos de reeducação porque alguém apareceu e disse que fulano é reacionário, sem qualquer fundamento, apenas porque não gostava dele ou porque gostava da mulher dele...

O que eu pergunto às pessoas, é: então vocês acham que eu fazia propaganda do regime? E então digo: lutar contra o apartheid é fazer propaganda de regime algum? Era o que eu fazia, e não tenho vergonha alguma de dizer isso: eu e outros meus colegas lutámos contra o apartheid, denunciando, filmando, fazendo várias peças no Kuxa Kanema, fazendo documentários. Inclusivamente, dirigi uma equipa de cineastas moçambicanos que partiu para a guerra em Angola, para mostrar que o apartheid também queria desestabilizar e ocupar Angola, tal como fazia em Moçambique. Produzimos o filme 5 Tiros de Mauser, filmado no deserto de Cahama, debaixo dos bombardeamentos do mirages sul-africanos. Se a isto se chama propaganda política, então sim, eu fazia propaganda política. 
Na situação em que nós estávamos, atacados todos os dias, faria propaganda ao apartheid?

V. A.: Apesar das dificuldades próprias de contextos como os nossos, o cinema moçambicano surgiu no âmbito de uma efervescência cultural grande do pós-independência, e se inseriu de forma central no debate público acerca do nacionalismo moçambicano e da criação do Estado. A altura, contou, inclusive, com a participação de nomes como Jean Rouch e Jean-Luc Godard. Acha que seja possivel hoje pensar em uma tradição cinematográfica moçambicana, no sentido de atribuir-Ihe uma organicidade e uma sistematização poética própria?

C. S.: A criação de uma cinematografia moçambicana foi um processo dirigido por Ruy Guerra, que foi uma grande contribuição para a formação de quadros moçambicanos. E foi-se formando um grande grupo de cineastas que vinham dar formação a custo de nada. Iam lá dar aulas grandes engenheiros de som, diretores de fotografia. Estiveram lá o Edgard Moura e o António Luís por exemplo, do Brasil, na área da fotografia, esteve lá a Vera Zaverucha também brasileira que ajudou a sistematizar todo o processo de produção do INC. E durante pouco tempo estiveram lá o Jean-Luc Godard e o Jean Rouch. Há todo um mito de que estas duas pessoas é que deram um grande impulso ao cinema moçambicano, mas isso não corresponde à verdade. Eles não chegaram a formar ninguém, estiveram lá para fazer aquilo que eram os seus objetivos pessoais.

O Jean-Luc Godard tinha um projeto dele, Sonlmage, que ele queria implementar, para estudo de um país que fosse virgem sob o ponto de vista de imagem ou de cinema. E Moçambique era isso: havia pessoas que nunca tinham visto a sua própria fotografia, onde o espelho ainda era alguma coisa recente. E era precisamente isso que lhe interessava: como as pessoas viam a sua imagem e a imagem daquilo que as rodeava. Eu lembro-me que ele fez uns experimentos muito interessantes. Por exemplo, numa aldeia do interior - nem era muito longe da capital - sob o ponto de vista do desenvolvimento humano dos indígenas, o Estado colonial pouco tinha feito, havia pessoas em aldeias muito próximas de Lourenço Marques que nunca tinham visto imagem. Então, o Godard foi lá com uma Polaroid e fez uma série de fotografias da aldeia, do ambiente, da vida na aldeia. As pessoas nunca tinham visto a vida da aldeia transposta para uma superfície de papel. E ele montou um expositor na aldeia com as fotografias. E aquilo foi a coisa mais louca que aconteceu naquela aldeia. Ele fotografou desde 
as pessoas até os animais e as casas. E as pessoas olhavam e ficavam espantadas, pois nunca tinham visto que aquela casa pudesse estar noutro sítio, mas que era a casa daquele cidadão da aldeia. A fotografia que mais sucesso fez foi a do galo da aldeia, que ganhou até um nome próprio depois disso. E as pessoas iam ao expositor e apontavam e falavam do galo. E depois foi a magia do som. Ele pôs as pessoas a ouvirem-se, o que foi uma coisa muito interessante. E era isso o que o Godard queria: fazer estudos sobre o impacto nas pessoas de se verem e ouvirem a si próprias. Esta é a minha interpretação do projeto SonImage - certamente haverá outras.

E o que eu pensava à altura era: em que medida isso poderia beneficiar Moçambique? Porque Moçambique estava a desbravar caminhos para uma cinematografia moçambicana. E isso podia ajudar bastante, em como poderíamos criar uma linguagem que o povo entendesse. Tratava-se de uma questão de simbologia. Mas Moçambique é feito de várias nações, então seria necessário perguntar não apenas como se viam as comunidades em torno de Maputo, mas como é que cada uma dessas nações iria entender a simbologia da imagem e do som. Eram línguas diferentes, eram nações diferentes. Isso era e ainda hoje é muito complicado. E por isso, grande parte das mensagens que são transmitidas nas campanhas sobre questões como SIDA (AIDS), ou as grandes pandemias, não sabemos se funcionam bem nas diferentes regiões do país. Podem funcionar no sul, mas a quatrocentos quilômetros da cidade há outra nação que fala uma língua completamente diferente, tem uma cultura diferente, é tudo diferente: é outra nação! E como essa linguagem das campanhas pode funcionar? O Jean-Luc Godard poderia ter ajudado a dar esse aporte para a criação de uma linguagem cinematográfica moçambicana. Ele não ficou muito tempo, não se entendeu muito bem com o governo e partiu. Mas era um projeto absolutamente dele, nós é que poderíamos ter tirado algum partido disso.

O Jean Rouch veio ligado à Universidade Eduardo Mondlane para fazer alguns filmes, porque ele tinha equipamento para cinema etnográfico, Super 8, que queria utilizar. E produziu alguns materiais etnográficos. Mas a antropologia na altura não era bem vista. O poder olhava para antropologia como se fosse alguma coisa que vinha para se intrometer nas questões internas da revolução. Ainda hoje, não gostam muito quando os antropólogos vão para lá. Só que, como os antropólogos ajudaram a criar alguns caminhos para o fim da guerra, então já vão com mais liberdade. Mas mesmo assim... É bom não esquecer de onde que 
vem a antropologia. Não é possível querer que pessoas saídas de uma guerra de libertação aceitem uma coisa que foi criada e utilizada pelo sistema colonial para entrar e colonizar efetivamente. A antropologia nasceu ligada ao colonialismo, e não se desfaz essa imagem de um momento para o outro. Era preciso realmente que a antropologia chegue de uma maneira completamente diferente e dialogue com o projeto do país, de alguma maneira.

Então é um mito que essas duas figuras tenham participado na criação do cinema moçambicano, um mito com que nós nos cruzamos em cada esquina. Eles não chegaram sequer a estar dentro do sistema que estava a ser criado para a produção de cinema em Moçambique. Tivemos algumas reuniões, algumas discussões, alguma experiência, mas não mais do que isso.

Agora, o Ruy Guerra, sim. O Ruy Guerra trabalhou conosco, participou em tudo o que fazíamos. Ele foi fundamental. E foi importante para a criação dessa linguagem que hoje é bastante utilizada - eu, por exemplo, uso bastante - o docudrama. E é interessante que ao mesmo tempo que ele dirigia a formação, aconselhava a direção do INC, contratava técnicos para virem dar formação, ele ia também produzindo os seus filmes, com os moçambicanos já formados em áreas técnicas e de criação. Aí o Brasil teve um papel importante na nossa formação, principalmente com o tipo de cinema que era produzido no Brasil na altura. Sobre a linguagem, não sei se já é possível considerar uma linguagem própria uma estética própria. $\mathrm{O}$ cinema moçambicano ainda é uma manta de retalhos. $\mathrm{E}$ também porque se está fazendo pouco cinema em Moçambique. Houve a fase das pessoas que construíram o Instituto Nacional de Cinema, depois o Kuxa Kanema, a produção cinematográfica do INC e que agora, como resultado das políticas neoliberais adoptadas pelos governos do país a partir de 1987, uma parte deles já não faz cinema, alguns já desapareceram, os que criaram suas próprias produtoras estão a enfrentar dificuldades extremas devido à inexistência de uma Lei do Cinema e da regulamentação e de fundos do Estado para a produção cinematográfica. Este é o grupo daqueles a que chamam os "antigos do cinema" que tentaram, de qualquer modo, criar uma própria linguagem, uma própria estéti$\mathrm{ca}$, mas mesmo assim, tudo muito retalhado. Existem filmes com novas abordagens ao nível da linguagem e da estética como é o caso dos filmes dos diretores Licínio Azevedo e Isabel Noronha. Por outro lado, há grupos de jovens que estão agora a aprender em cursos dados pela Associação Moçambicana de Cineastas (AMOCINE) e outros em cursos de Institutos ligados a Universidades e que têm 
as suas próprias abordagens. Por isso é prefiro falar do cinema que se faz em Moçambique, ao invés de "cinema moçambicano". Não há dúvida nenhuma que há um caminho para esse "cinema moçambicano" desde o pós-independência até agora, mas é um caminho inventado por nós. Há diversos estudos sobre esse assunto feitos por várias universidades no mundo.

V. A.: Suas atividades no espaço da comunicação surgem imediatamente após a independência, num trabalho intenso em Cabo Delgado. De que se tratava, exatamente, esse trabalho, e o que o moveu particularmente a estar nessa província? Havia algum sentido político nessa opção? De que forma esse período seria aproveitado na sua produção posterior?

C. S.: Nasci em Maputo, na altura Lourenço Marques e lá fiz toda a minha juventude. Depois, saio de Moçambique e vou para a Bélgica onde adquiro o estatuto de refugiado político das Nações Unidas. Algum tempo depois, vou para a Argélia e Tanzânia e junto-me ao Movimento de Libertação FRELIMO - Frente de Libertação de Moçambique. Vou então para o sul da Tanzânia, onde a FRELIMO tinha um grande campo de treino de guerrilha, mas tinha também militantes de Angola, do Zimbabué, e da África do Sul a serem treinados. Faço o treino de guerrilha e depois sou enviado para as zonas libertadas da ocupação colonial portuguesa, em Cabo Delgado - província no norte de Moçambique - que era junto à fronteira com a Tanzânia. Naquela província enorme, a guerra era muito intensa e já estava bastante avançada. O exército português precisava manter aquela província bem defendida para evitar o alastramento da guerra. Por isso, tinham grandes quantidades de tropas e armamentos e por outro lado, a FRELIMO também tinha os seus melhores grupos de guerrilha naquela zona. Então fui enviado para Cabo Delgado, executando múltiplas tarefas, entre elas o trabalho de informação e propaganda. Fiquei lá até ao fim da guerra e quando esta acabou, continuei por lá. Não queria continuar a ter atividade no exército, mas continuei ligado até 1980.

Interessava-me conhecer a província. Já conhecia bem a zona Norte chamada Planalto dos Macondes. Faltava-me conhecer o resto, as regiões dos Macuas e dos Kimuanes. Criar formas de - mais uma vez, essa questão da unidade nacional e da independência - mostrar às pessoas quem éramos. Porque mesmo nesta província onde eu estava, havia uma nação que eram os Macondes, divididos entre os do planalto e do litoral; havia outra nação que era a dos Macuas, que 
eram divididos entre os do Norte e os do Sul, na mesma província; mais os Kimuanes e poucos Ajauas e Swahilis. Falavam-se muitas línguas e dialetos, numa só província. Quando terminou a guerra, fui às zonas que eram ocupadas pelo exército português - isto depois do Acordo de Lusaka [assinado a 7 de setembro de 1974 entre a FRELIMO e o Estado português que determinou o fim da guerra e levou Moçambique à independência] - na região Norte da província, onde hoje há petróleo e gás natural. E encontrei uma situação bem interessante: os homens falavam em Swahili, as mulheres respondiam em Kimuana - não podiam falar Swahili, porque esta era língua de homens, mas tinham de saber Swahili, senão não entendiam o que o homem dizia. A criança desde a sua nascença, se é rapaz fala Swahili com o pai e a mãe, mas tem de entender Kimuane para escutar a mãe; se é rapariga, fala Kimuane com o pai e a mãe, mas tem de entender o Swahili para ouvir o pai. Então, aprendem logo as duas línguas, uma para o pai e outra para a mãe.

Na área da comunicação social, meses antes da proclamação da independência, criei um grupo de correspondentes populares em Cabo Delgado. Ministrei cursos básicos de elaboração de notícias ou de pequenas estórias em todos os distritos da Província e todos os dias esses correspondentes enviavam via rádio de comunicações do governo, ou por carta através da rede rodoviária - que na altura ainda funcionava - o que havia de atividades nas suas localidades ou aldeias. A ideia era possibilitar a essas pessoas que nunca tinham tido a oportunidade de se pronunciar, que a sua voz fosse escutada. Estas informações eram trabalhadas por um grupo de colaboradores e depois enviadas para a Rádio Moçambique (Emissora Nacional) que as difundia por todo o país. Por outro lado, existia um emissor de fraca potência, que apenas abrangia a Província, onde colocávamos essas notícias e pequenas reportagens que fazíamos em vários lugares da Província.

E isso foi encontrar alguma coisa para mim próprio e que me dava prazer em fazer. Não podia fazer cinema porque na altura não havia em Cabo Delgado qualquer estrutura onde me pudesse enquadrar. Consegui arranjar uma máquina $16 \mathrm{~mm}$, uma Bolex Paillard, daquelas de corda, para ir filmando algumas coisas.

Fiquei lá de 1974 a 1978, fazendo esse tipo de atividade e também trabalhando em tudo o que era ligado a projetos sociais, económicos. Era uma espécie de Comissário Político. Na verdade, a minha função era de Secretário Provincial 
para o Trabalho Ideológico da FRELIMO. Foi um momento interessante em que eu aproveitei principalmente para conhecer as etnias da região. E conheci-os bem, fiz muitas e muitas amizades e era muito querido pela população. Eu era muito jovem, tinha 22 anos. Participava também na resolução de conflitos graves. O contato com essas populações se dava, sobretudo, em português, com intérprete.

Então, o que essa temporada em Cabo Delgado me deixou, foi esse conhecimento das pessoas e de trabalhar bastante, dia e noite, com e para elas. Eu não entendia nada de agricultura, mas chegava aos lugares e juntava-me aos camponeses, e íamos pensando como fazer a agricultura, como criar sistemas básicos de rega etc. Depois, tentávamos pôr algumas coisas em prática. Passava a ir lá regularmente para ver se as coisas estavam bem, do que é que eles precisavam, ajudava a estruturar os seus papéis para o controle da produção. Ajudava as pessoas a desenvolverem alguma coisa. Claro que fiz uma sala de cinema numa aldeia (risos)! Era um grande projeto do Ruy Guerra, colocar cabines de cinema nas aldeias, em todo o país. E esse foi o primeiro cinema que foi construído dentro desse projeto e foi produzido por mim. E ainda hoje está em pé! Consistia num palco com um écran e uma cabine de projeção, tudo feito em ferro-cimento. Mas já nada funciona mais. Não há mais projetor, não há mais filmes.

Por fim, Cabo Delgado foi uma grande aprendizagem do que era o país, que me ajudou bastante na produção de cinema e na criação dos meus filmes, posteriormente.

V. A.: A partir de 1972 você se encontra na Bélgica sob a condição de refugiado político. Essa passagem de sua vida tem certa analogia com um exílio por que passou sua tia, Noémia de Sousa. Fora de Moçambique, você esteve em contato mais intenso com ela? Como foi sua relação com este que é um dos maiores nomes da cultura moçambicana? Em que medida a arte da poetisa se relaciona com a sua arte?

C. S.: Só conheci a Noémia em 1969, em Paris, numa altura em que eu estava a tentar ir para a Holanda, para refugiar-me lá. Eu vou a Lisboa e depois a Paris. Tinha acabado de fazer 16 anos. Encontro-me primeiro com meu irmão - eu tinha um irmão que eu conhecia mal, ele partiu de Moçambique quando eu tinha 5 anos. Conheço esse meu irmão, que vivia em Lisboa e estabelecemos uma forte relação. Não tínhamos relação nenhuma anteriormente, apenas comunicáva- 
mos por carta, nunca nos tínhamos visto. Ele sim, ele lembrava-se de mim, mas eu não tinha a mínima ideia de quem ele era, apenas o conhecia por fotografia. Esse meu irmão, o Guilherme, teve uma grande influência sobre mim. Ele fez também cinema, foi jornalista na BBC e começou a escrever, estão agora a ser publicados os livros dele. Depois disso, fui a Paris e é quando me encontro com a Noémia. Passamos uns momentos fortes, muito intensos, discutindo o país, a política colonial-fascista imposta pelo estado português e os caminhos para luta pela independência de Moçambique. A Noémia de Sousa, na altura, era casada com um poeta moçambicano, o Gualter Soares e ficamos noites e noites a discutir o país, o movimento de libertação, olhando um pouco para como as coisas seriam mais tarde. $\mathrm{E}$ isso foi bastante forte para mim.

Tinha só 16 anos, vivia em Moçambique, estava a tentar ir para Holanda conseguir refúgio, mas não consegui, porque era menor e não tinha qualquer maneira de as Nações Unidas me aceitarem como refugiado político. Então voltei para Moçambique. Mas esse espaço com a Noémia foi importantíssimo. Com a Noémia e com o Guilherme, foram momentos importantes na minha vida, como cineasta e, por que não, como político?

Mais tarde vou então para a Bélgica. Vou de Moçambique a Portugal, fiquei lá uma semana, passo a salto a fronteira com a Espanha e dali vou para França, passando os Pirineus a pé, clandestino. Quando chego a Paris novamente vejo que aquilo estava feio por lá, estavam a prender muitos clandestinos. Então fui para Bruxelas - a minha ideia era voltar à Holanda - onde o meu irmão já estava a viver, como refugiado. E acabei ficando por lá, vivi pouco lá, mas foi muito intenso. Fiquei e fiz tudo o que podia fazer em Bruxelas. Pedi refúgio político, foi-me concedido quase que imediatamente e arranjei emprego: era limpador de casas de banho de mulheres no Banco de Bruxelas. Era uma coisa que nenhum dos limpadores aceitava fazer, porque a maior parte dos que faziam serviço de nettoyage eram árabes; e árabes não limpam casas de banho de mulheres! E eu aceitei logo. Tive alguns dissabores com os árabes por ter aceitado o emprego, fui perseguido porque achavam que eu era árabe também! Mas pouco tempo depois, fui trabalhar na empresa de Metro de Bruxelas, fiz lá um curso e era motorista do pré-metrô, ganhava razoavelmente bem.

Bruxelas influenciou-me muito, também, por conta daqueles movimentos que havia por lá - como o Partido Comunista Português, os Marxista-leninistas. Eu não gostava muito deles. Eram todos muito progressistas, muito faladores de 
políticas antifascistas, mas quando tocavam as colônias: aí, a coisa era diferente! A solução para as colónias era um acordo de autodeterminação, mas nunca a independência total e completa! Então eu não podia me dar bem com aquelas pessoas. Mas depois encontrei movimentos armados portugueses e, esses sim, esses eram próximos dos meus ideais. O ARA (Acção Revolucionária Armada), foi o movimento com quem me dei mais, tinha encontros com eles regularmente. E foi um momento bom, com esses movimentos armados. Depois liguei-me bastante aos movimentos anarquistas que, à altura, andavam em Bruxelas com bastante força.

Fiz o primeiro contato com a FRELIMO a partir da Holanda e depois em Bruxelas, quando o Marcelino dos Santos passou por lá tivemos uma longa conversa, algumas semanas depois passou o Chissano. Em seguida, o Guilherme (meu irmão) e eu contatámos a FRELIMO formalmente, para sermos integrados ao movimento. Escrevemos uma carta a pedir que nos aceitassem no movimento e cada um de nós escreveu a sua carta. A carta do Guilherme dizia assim, genericamente: "eu aceito a FRELIMO como legítima representante do povo moçambicano na sua luta pela independência"; e a minha carta dizia: "peço que a FRELIMO me aceite como seu membro". Então a minha integração foi aceita de imediato, mas a do Guilherme, não!

E acabei por ir para a Tanzânia. A entrada para o movimento foi também um pouco conturbada. Eu conhecia bastante gente ligada ao movimento. Fui de Bruxelas para Argel, fiquei lá um tempo, e depois fui para a Tanzânia. E a partir do momento que estou dentro do movimento, penso que tenho acesso a todas as publicações e outros documentos do movimento. Estava habituado ao movimento anarquista. Chego a Argel, havia lá o escritório, acho que o maior escritório do movimento em África. Cheguei lá, apresentaram-me às pessoas e comecei a andar ali pelo escritório, entrei na biblioteca, até que veio lá uma senhora que me disse: "o camarada não sabe que não pode estar aqui?" Ao que respondi: "não posso? Por quê?" E ela disse: "é porque isso não é para qualquer pessoa". E eu: "mas eu não sou qualquer pessoa!" E isso caiu muito mal em mim. E disse-me ainda que eu falava a português como os colonos. Ela queria que eu falasse com um sotaque moçambicano, um sotaque que as pessoas que não são negras, inventaram para dar um ar de que estão com os negros, que falam como os negros, criaram aquilo que eu chamo "sotaque da FRELIMO". Nada menos do que um sotaque de brancos querendo imitar os negros. 
V. A.: Sua relação com a FRELIMO é marcada por intermitências. Da experiência do combate, sua postura se alterou até o afastamento dessa instituição. Quais são os signos que caracterizam sua relação com a FRELIMO? O afastamento da instituição teve impacto no seu trabalho cinematográfico? Como é sua relação com o partido hoje? Como analisa sua atuação como instituição máxima de gestão pública em Moçambique atualmente?

C. S.: O meu afastamento da FRELIMO, na verdade, começa em finais de 1977, quando a FRELIMO se transforma em um partido - antes era uma Frente - Marxista-Leninista. É nessa altura em que inicio todo um processo para me afastar, porque pensei que os objetivos pelos quais eu me liguei à Frente estavam cumpridos: estávamos independentes. Não estava muito de acordo com o Leninismo da nova organização: sabia que isso iria fazer aquele movimento descambar em outros caminhos.

Estando eu ainda em Cabo Delgado - na altura era Secretário Provincial para o Trabalho Ideológico da FRELIMO, portanto o novo partido - pedi, em reunião com o Comitê Político Provincial, do qual eu fazia parte, para me retirar, pois achava que já tinha dado a minha contribuição e queria fazer outras coisas queria fazer cinema, por exemplo. Meu pedido foi muito mal recebido. Entretanto, em 1978, é indicado para dirigir a província de Cabo Delgado um destacado membro da "nomenclatura" e ele não gostou nada do meu pedido para sair do partido para dedicar-me a outras coisas que não a vida partidária. E então, nessa altura, fiquei retido em Cabo Delgado desde essa época até o final de 1979, sem trabalho. Há uma expressão que se usa muito na FRELIMO que diz: "aguarde novas ordens"; isso quer dizer que podes ficar meses e até anos, sem fazer nada. Recebia o meu salário como militar, tinha as minhas regalias, mas não fazia absolutamente nada, "aguardando novas ordens". Entretanto, falei diretamente com os órgãos centrais do partido que não sabiam o que se estava a passar, pois não tinha havido comunicação entre a estrutura superior da província e os órgãos centrais da FRELIMO acerca disso. Aí, saí de Cabo Delgado para Maputo e liguei-me ao cinema.

Durante esse tempo, enquanto "aguardava novas ordens" lembrava-me sempre de uma coisa que me tinha dito o diretor de uma revista latino-americana Cadernos do Terceiro Mundo, o [José Guimarães] Neiva Moreira. Ele esteve na independência de Moçambique e fez uma visita a Cabo Delgado logo depois. Cadernos do Terceiro Mundo foi uma revista que sempre falou de Moçambique, 
sobre a luta pela Independência, sobre a revolução. Ele foi visitar, principalmente, a zonas libertadas que tinham sido palco da luta pela independência e eu fui acompanhá-lo. E quando acabou a visita, perguntei-lhe "o que é que achou o Neiva Moreira?", e ele disse-me: "olha, vou dizer-te uma coisa, sei vais ficar zangado comigo, mas tenho de dizer. Essa vossa revolução vai durar muito pouco tempo!" Eu, saído da Luta de Libertação, não podia aceitar que uma pessoa do peso do Neiva Moreira pudesse dizer tal barbaridade. Fiquei zangado com ele, porque ele disse-me: "já percebi que há aí algumas coisas que não vão funcionar: dinheiros, casas, terras, negócios e até carros, tudo isso vai dar problemas. Alguns vão querer mais e mais do que a maioria. Daqui a alguns anos falamos". Embora zangado com ele, sempre fui pensando naquilo e na realidade fui assistindo ao desmoronar daquele grande sonho que era a construção de um novo país livre, fraterno e com as mesmas oportunidades para todos.

Assisti a coisas bárbaras e fui percebendo o que era essa coisa do partido Marxista-Leninista - que fosse Marxista ainda aceitava, mas Leninista, já me fazia muita confusão (risos). Pensava sempre nos gulags da União Soviética, nos escritores e artistas chamados "inimigos do estado" que eram para lá enviados, lembrava-me dos amigos de refúgio político na Bélgica vindos da Albânia, da Hungria, da Checoslováquia, das suas tristes histórias e de suas famílias.

E assim fui caminhando, umas vezes juntando-me mais ao partido, como durante a guerra de desestabilização. Por detrás de tudo havia uma guerra contra nós movida pelo apartheid e que, na verdade, para fazer frente a ela só estando dentro do partido; estando fora, sentíamo-nos fora da luta contra o apartheid. Então, acabei continuando, dentro ou fora, mas sempre ligado àquele partido. Só me desligo totalmente quando o partido assume uma atitude absolutamente neoliberal (e diga-se, o neoliberalismo mais horrível possível) e quando começo a ver que tudo o que levou à Luta de Libertação e à independência tinha terminado. Já não existia mais nada a não ser uma sociedade baseada nos valores do capitalismo selvagem. Era para onde os sucessores de Samora Machel, nos queriam levar. E achei que aí devia separar-me, não podia fazer parte deste grupo, não podia fazer parte daquilo em que se estava a transformar aquele partido: numa grande máfia. Começaram então os assaltos aos bens comuns, a delapidação do Estado e da banca estatal, os assassinatos, os raptos, as grandes traições dentro do próprio partido. E por isso, fui-me desligando.

Tenho grandes críticas a fazer à FRELIMO e à forma como ela é dirigida. Agora 
temos um novo presidente [Filipe Nyusi]. Gostaria de voltar a fazer parte deste partido, mas é preciso que as coisas mudem. Até agora nada mudou. Já passou bastante tempo e nada de diferente aconteceu. Penso que não vou voltar a ligar-me a esse partido, enquanto aqueles a quem um académico moçambicano chamou publicamente de "os cachorros do chefe" não forem retirados.

Não é que eu seja contra a FRELIMO. Sou contra esta FRELIMO belicista, que leva o povo à morte, que leva o povo à fome. Esta FRELIMO da corrupção onde as pessoas constroem fortunas roubando dinheiro ao Estado. Um partido que aprovou, agora há pouco tempo, o relatório de contas do exercício económico de 2014 sem sequer uma pergunta, sabendo justamente que o exercício desse ano foi de delapidação dos cofres do Estado.

Eu viajo bastante pelo país, vou a todas as províncias e vejo como as pessoas estão vivendo: sofrendo, morrendo de fome, sem água nem saneamento, com falta de assistência médica e medicamentosa, sem um sistema de educação credível. Não foi para isso que se lutou pela independência. É um país que está abandonado por aquela elite dentro da FRELIMO que apenas pensa na riqueza fácil, tal como os colonialistas faziam.

E isso tem a ver com o meu trabalho. Faço cinema e toda a minha vida dentro do cinema foi tentar criar um país melhor, com pessoas melhor informadas, com uma visão nova sobre a independência, sobre o "Homem Novo" - não aquele da FRELIMO, mas um homem digno, homem sério, homem dedicado aos anseios do povo que sofre. Porque só assim poderemos construir o país que tanto desejamos. Todos os meus ideais passaram para os filmes que fui fazendo e que vou fazendo, quando tenho condições para isso.

Infelizmente não podemos ver todos os filmes que fiz, porque a maioria foi feita em película, 16 mm e estão todos guardados não sei em que condições, no Instituto Nacional de Audio Visual e Cinema. Aos quais nem eu próprio tenho acesso. 


\section{ISABEL DE NORONHA}

IA ATLÂNTICA: Sua trajetória pessoal de chegada ao cinema é marcada por uma crise vocacional intensa solapada pelas políticas públicas de engenharia profissional praticadas naquele Moçambique dos anos de 1980. Fale-nos sobre esse episódio, considerando, sobretudo, como foi para você ter o direito de escolha profundamente atravessado pelos interesses de um Estado centralizador? O que o exemplar episódio vivido por você nos ensina a respeito do cidadão moçambicano daquele período? De que forma enxerga esse acontecimento depois de tanto tempo? É possível dizer que o acaso que a levou para o cinema representou uma "salvação" oportuna?

ISABEL DE NORONHA: Talvez isso seja uma forma de olhar as coisas tanto tempo depois, com a distância emocional e com a distância que a racionalização dessa experiência pode dar, vinte anos depois, trinta anos depois. Mas na altura não era assim que as coisas se passavam, ou não era assim que as pessoas da minha geração viviam essas coisas. Não era apenas no momento da escolha que esse conflito se dava, nós vivíamos permanentemente num profundo conflito entre aquilo que nós desejávamos ser e aquilo que nós podíamos ser, dentro desse contexto de Estado centralizador. Mas a leitura que nós fazíamos desse conflito, na altura, era uma leitura numa outra chave: de um lado estava aquilo a que nós devíamos, não digo obediência, mas emprestar alguma espécie de esforço, ao serviço do desenvolvimento desse país que queríamos construir - nós achávamos realmente que isso era tarefa nossa; por outro lado havia o desejo que nós tínhamos de fazer as nossas coisas individuais, aquelas com que sonhávamos para nós mesmos. Mas não era assim claro e dado que tu tinhas um desejo individual e que esse desejo era atravessado por um desejo político do Estado. Quer dizer, nós e esse projeto político, esse projeto de país, não éramos duas coisas: nós éramos parte desse projeto, sentíamo-nos parte dele e achávamos que era nosso dever fazer alguma coisa nesse sentido. Então, era aí que residia o conflito: entre o dever quase que moral de participar, dando tudo quanto fosse preciso para construir o nosso país e um desejo legítimo como indivíduo de ter as suas preferências, a sua vocação, as suas escolhas, as suas paixões. Como sair disso? Não era muito claro, como é que tu gerias tudo isso: como é que tu fazias 
para ser, para ser a pessoa que tu eras, dentro deste contexto.

Porque tu já eras muita coisa antes de tudo isso acontecer... Coisas constitucionais, tinhas uma personalidade, uma identidade. Eu tinha dez anos à altura da independência, então, eu entro na adolescência já nesse processo de socialismo pós-independência. E a gente se construiu - toda a gente da minha geração como indivíduos partidos entre essas duas questões, entre o coletivo e o individual, sem saber como casar as duas coisas, porque não havia espaço para o individual no meio desse gigante coletivo que era "o povo", que era "o país" que todos nós tínhamos por tarefa construir. Tu começavas por ter de silenciar toda a tua identidade: eu sou filha de intelectuais, o meu pai era médico e minha mãe era assistente social, os dois trabalhavam para o Estado português, o meu pai era inspetor de Saúde e minha mãe era diretora do Instituto de Serviço Social, tinham vindo para Moçambique para executar essas tarefas na função pública, o meu pai vindo de Goa em 1928 e a minha mãe de Portugal em 1962. E eu fui criada num ambiente em que se pensava sobre as coisas, se lia sobre tudo e se falava livremente sobre qualquer coisa. Tínhamos em casa uma estante com centenas de livros à nossa disposição e nunca os meus pais disseram: "este é para tua idade e este não é". A gente ia lá, pegava num livro, abria, o que conseguisse entender, entendia, o que não conseguisse entender, voltava a guardar. $\mathrm{E}$ talvez mais tarde voltássemos a abrir o mesmo livro e a compreendê-lo melhor. Nunca ninguém nos disse: "só podes ler isso, só podes falar daquilo". Fazíamos o que nós queríamos, na realidade e tínhamos contato com tudo, o pensamento do mundo inteiro estava lá, na estante da nossa casa, nos discos de vinil, nas dezenas de estações de rádio que o meu pai escutava todos os dias, nos jornais diários que já estavam em baixo da porta quando nós acordarmos, nos semanários que ele comprava à tardinha, nas revistas mensais que chegavam do estrangeiro pelo correio. E eu tinha orgulho dos meus pais, no trabalho de cada um deles, sempre acreditei que eles trabalhavam para o bem das pessoas, de todas as pessoas independentemente da raça e da cor. Em 1974, quando foi o 25 de Abril, o meu pai, já reformado e com 74 anos, dava consultas num posto de saúde no bairro periférico de Benfica e a minha mãe geria projetos de melhoria das condições de vida em áreas suburbanas como Bairro dos Pescadores e Bairro do Aeroporto.

Mas após a independência, eu nem sequer podia dizer que era filha de intelectuais, porque já isso era um motivo de estigma, porque o que era correto era 
ser filho de operários e camponeses. E havia a questão da cor [da pele], que era evidente. Antes, eu não tinha a cor certa porque era "café com leite" - cor de branco misturado com indiano - na escola primária colonial era discriminada por isso. Depois da independência também não tinha a cor certa, não era negra; embora isso não fosse dito, porque era proibido ser-se abertamente racista, fazia-se sentir muitas vezes nas relações quotidianas. E tu cresces com a sensação de que tu nunca és aquilo que devias ser. Ou tu nunca podes ser aquilo que tu és. Ou tu nunca estás certa naquilo que tu és, na tua essência mais fundamental. Então, em 1981 chegou a idade da escolha do curso a seguir. Era uma coisa muito importante chegar ao fim da décima primeira classe e não ter sido tirado na sexta classe para servir ao exército ou ir para Cuba para a llha da Juventude; não ter sido tirado na nona classe para ser professora primária ou secundária; não ter sido chamada para ir para a União Soviética para um curso militar ou de segurança; não ter ido para o Campo de Reeducação por indisciplina ou por gravidez precoce... Havia mil coisas que aconteciam entre o primeiro ano do liceu e o último. Nós chegávamos ao último ano da escola secundária talvez um terço ou um quarto das pessoas que tínhamos entrado na quinta classe - e não era porque as pessoas reprovavam, mas porque eram tirados para essas outras "tarefas". Portanto, já era um privilégio ter chegado ao fim do ensino secundário e muito mais - como se considerava na época - um privilégio receber uma bolsa de estudo para estudar fora, após a décima primeira classe. A mim, atribuíram uma bolsa para estudar História na Tchecoslováquia. Mas imagina, estudar História Universal na Tchecoslováquia, em tcheco, durante seis anos... E o sítio para onde nós íamos era a quarenta quilômetros de Bratislava, um antigo convento de freiras... E o programa do curso continha quarenta horas de estudo na faculdade e quarenta horas de estudo coletivo obrigatório... E só teríamos direito a sair para ir à cidade ao fim de semana... (risos). Portanto, era um internato, nos moldes socialistas mais horríveis, mais estritos. Eu ainda cheguei a frequentar durante três meses o curso preparatório, de latim e alemão, que nos habilitaria a aprender depois a língua Tcheca... Era uma verdadeira tortura... E eu não gostava de História, não queria sair por seis anos do país, meu pai já tinha oitenta e um anos nessa altura.... Então, eu disse que não. Mas o tu dizeres "não" tinha sempre custos, qualquer "não" tinha custos. E havia uma série de medidas que iam sendo aplicadas sucessivamente aos "renitentes", que era como eles chamavam aos que diziam "não". 
Eu sabia que eu ia ter uma punição e a minha punição foi ter de ir para a Faculdade de Educação. A Faculdade de Educação era a punição mais "soft", havia a punição mais severa, que era o Serviço Militar Obrigatório - estávamos em guerra - e por fim, havia o Campo de Reeducação. Eram as três coisas que me podiam acontecer por ter dito "não" e, portanto, eu tive sorte. Então, eu fui para um curso de formação de professores de português e inglês. $E$, mesmo que não fosse o que eu mais gostaria de estudar - eu queria estudar Psicologia, mas não havia esse curso, que era considerado um curso burguês e desnecessário num "país onde todos seríamos felizes", onde não haveria "problemas sociais" - fiquei contente, pensei que iria estudar literatura, estudar linguística, ia estudar coisas bonitas de que eu também gostava. Estava conformada, contente até por ir dar aulas de português, ensinar os alunos a expressar as suas ideias, a ler outras leituras, a criar. Mas eis que no final do segundo ano do curso - que era de português e inglês, só que nós não tínhamos tido inglês na décima e na décima primeira classe, porque não estava no currículo, e eu não sabia praticamente nada de inglês - nos disseram: "todos os alunos vão dar aulas de inglês, porque não há professor de didática de português"... Então eu disse: "como é que eu vou dar aulas de uma língua que eu não sei nem pra mim, como vou ensinar uma língua que eu nem sei falar?" Então, tive de dizer o meu segundo "não".

O segundo "não" já era demais. Significava que eras muito "renitente" mesmo, dava direito a qualquer coisa de muito mau. E aí fiquei à espera, numa espécie de "terra de ninguém", numa fronteira entre.... Como posso explicar? Eles não te fazem nada, mas não te abrem nenhuma porta. Bati a inúmeras portas à procura de trabalho de escrita, em jornais, revistas, na Rádio. Até encontrei pessoas simpáticas, mas ninguém queria arriscar-se a dar-me trabalho, porque eu era uma "fugista" da Educação. Então tu ficas em suspensão. Tu perdes o direito ao trabalho, que é a coisa mais elementar que um cidadão pode ter... E estás sob ameaça permanente de que alguma coisa de mau, que tu não sabes o que é, aconteça. Acho que deve ser a coisa mais difícil que pode haver na vida, tu ficares neste estado de suspensão de direitos, digamos... Mas ao mesmo tempo isso não é dito, é uma coisa que não é declarada: é um fantasma que está lá, atrás de ti, mas não podes te queixar disso, tu não tens nenhuma evidência de nada, nenhuma evidência de que aquela violência está a ser exercida contra ti. E de fato, eu fiquei nessa suspensão entre 1983 e 1984... Precisamente o ano da Operação Produção, em que os "improdutivos" estavam a ser tirados à força da 
cidade para o campo. Os jovens eram parados na rua e se não tivessem cartão de estudante ou de trabalho, entravam no camião e eram levados diretamente para Niassa, Cabo Delgado. Eu já não tinha cartão de estudante, ainda não tinha cartão de trabalho, e tinha de andar na rua, nessa minha condição forçada e desesperada de "improdutiva".

E quando tu dizes "salvação", não sei se é de facto uma salvação. Porque tu começas a viver num clima de terror, mas ao mesmo tempo é como se tudo fosse um outro universo, outra realidade. É como se tu estivesses de fora, a ver aquele mundo a acontecer. É como se tu tivesses ganho uma distância que te permite olhar para aquele mundo como ele é e não como tu o vias quando tu fazias parte dele. É como se tu estivesses a ver um filme a acontecer num écran. Então, foi "salvação" no sentido de eu poder ser incluída de novo naquele mundo de que era preciso fazer parte e fazer alguma coisa de que eu gostava. Mas na altura eu nem sabia se eu gostava ou não gostava. Foi a única porta que se abriu e eu disse "bom, eu vou lá!". Ainda por cima uma coisa fascinante como o cinema! Mas não é que foi logo maravilhoso, não é que foi logo fantástico. Eu fiquei de 1984 a 1987 a trabalhar como assistente de produção, porque eu não tinha tido nenhuma formação nessa área; eu própria escolhi começar de baixo porque em todo esse processo anterior eu tinha ficado extremamente fragilizada, com uma autoestima quase zero, achando que como pessoa, como cidadã, como profissional, eu não valia grande coisa. Precisava de estar num lugar onde não me exigissem muito, ter tempo e espaço para aprender na prática, aos poucos, o que era isso de fazer cinema. E trabalhar como "assistente de produção" dava-me a possibilidade de entrar em todos os sectores, ver um pouco de tudo. Às vezes significava coisas maravilhosas, como poder sentar-me a ver os realizadores discutirem um guião, entrar no laboratório e ficar a ver cada processo, assistir a filmagens e à montagem do Kuxa Kanema, dos documentários, mas outras vezes significava coisas muito complicadas como inventar de uma hora para outra maneira de meter no primeiro avião uma equipa que o Presidente Samora mandara chamar imediatamente, para ir filmar uma coisa que ele estava a ver numa província e queria que fosse filmada; ou ser responsável da logística do filme $O$ Tempo dos Leopardos e dar de comer às pessoas de uma equipa de 80 pessoas, entre técnicos e atores, mais 300 figurantes, habitantes da ilha da Inhaca, onde o filme foi rodado, numa época em que não havia nada para comer nem beber e tudo o que tínhamos vinha de Maputo, de barco e chegava quase sempre só metade. 
Ou servir chá com açúcar, controlar as rações de bolachas, andar toda a noite no escuro durante as filmagens noturnas, num mato cheio de cobras, com cantis de aguardente - não havia café - à cintura para acordar os técnicos, controlar o diesel para abastecimento do gerador, numa ilha em que diesel era "ouro" porque dele dependiam os todos movimentos dos barcos para Maputo. Enfim, imagina essas responsabilidades, para uma jovem de 19 anos que eu era.

Do final de 1985 até 1990 - que foi quando eu saí do INC - trabalhei no Kuxa Kanema, a fazer cinema de guerra, em zonas de guerra. Essa parte não teve nada de maravilhoso. Então, posso dizer que a única "salvação" possível para qualquer jovem naquela época, era encontrar uma porta de entrada para alguma coisa que seria sempre igualmente difícil, igualmente dura, com as suas maravilhas pelo meio, mas não havia nenhum caminho em que tudo fosse uma maravilha.

Se é possível dizer que minha vida foi atravessada por alguma coisa, foi pela história do meu país, foi por esse processo que começou por ser o colonialismo, depois foi uma revolução, depois foi a desilusão de uma revolução, depois foi um Estado neoliberal e agora recentemente foi um Estado autoritário, a que alguns preferem chamar uma ditadura. Então há um atravessamento sim, mas é um atravessamento por um processo histórico, não apenas por uma única coisa que é um Estado centralizador socialista. Porque depois há o Estado centralizador capitalista que não é melhor, e antes de tudo isso houve o Estado centralizador colonialista... (risos).

V. A.: Sua entrada no cinema se deveu, sobretudo, ao contato com certo grupo que, envolvido com os primórdios do cinema moçambicano, apresentou-lhe a oportunidade de encontrar um ofício que te subtraísse da condição civil de "improdutiva", segundo os parâmetros da época. É possível dizer que aquele grupo compunha uma geração da arte e da cultura moçambicana? O que movia essa geração? Como ela se relacionava com a geração imediatamente anterior, a que havia consolidado a emancipação política de Moçambique?

I. N.: De facto, essas pessoas que eu encontrei, eram o Camilo [de Sousa], o Pedro Pimenta, o Licínio [de Azevedo], e o Luís Carlos Patraquim, os quatro que eu encontrei, e que achei que eram tão improdutivos quanto eu, porque estavam às onze da manhã, à porta de um prédio na [avenida] Julius Nyerere a conversar (risos). Quem é que estaria às onze da manhã à porta do prédio a conversar na- 
quela época? Ninguém! As pessoas que trabalhavam estavam nos seus locais de trabalho, os estudantes estavam na escola. Eu já conhecia o Camilo, desde 1982, em Pemba; eu sabia quem ele era, sabia que ele fazia cinema, eu sabia quem eram aquelas pessoas. Cruzávamo-nos nas festas, vivíamos na mesma cidade e eu via o nome deles na ficha técnica do Kuxa Kanema. Estas pessoas que faziam o Kuxa Kanema, para a minha geração, eram uma referência muito importante. Porque o Kuxa Kanema era a nossa única referência sobre o país: nós só sabíamos o que se passava no país através do Kuxa Kanema. Algumas coisas saíam nos jornais, algumas coisas apareciam na revista Tempo, que na altura era dirigida pelo Mia Couto e tinha crônicas sobre o país bastante interessantes.

Mas o Kuxa Kanema era aquilo que nos dava semanalmente a imagem do país. E não há nenhum jovem da minha geração que não fosse uma vez por semana ao cinema só para ver o Kuxa Kanema. Era como ligar a televisão para saber notícias. Bom, a gente ia e no fim aparecia aquela ficha técnica. O Kuxa Kanema era uma coisa muito importante para nós e aquelas pessoas que estavam entre aqueles nomes eram os nossos heróis: iam para a guerra de Angola, iam filmar o rei de Marrocos, iam para a União Soviética com o Samora [Machel], acompanhavam-no em todas essas viagens, pelo mundo inteiro, filmavam a Independência do Zimbabué. Quer dizer, eram figuras para nós meio míticas, de que só víamos passar os nomes.

Então, sim, essa geração que incluía cineastas, que incluía escritores, pessoas de teatro, pintores, escultores, fotógrafos, músicos, era uma geração que para nós tinha uma importância muito grande e que era uma grande referência. Tanto que, grande parte do meu tempo fora da escola, era passada na Associação dos Escritores Moçambicanos. Na altura, eu não tinha nenhuma intenção de escrever ou de publicar nada, mas nós tínhamos lá um grupo de teatro, tínhamos um grupo de música, a Associação dos Escritores Moçambicanos era a única associação de artistas que havia nessa altura (não havia associação de músicos, não havia de cineastas, não havia nada disso). Era um lugar que tinha um espaço muito bom, muito bonito, onde se reuniam todas essas pessoas: iam músicos, iam pintores, iam escritores, iam pessoas de teatro. Era um ambiente cultural de intelectuais das várias vertentes, das várias artes. E para mim era um espaço muito particular, porque era a mesma casa onde antes era o Instituto de Serviço Social, que tinha sido criado e dirigido pela minha mãe durante mais de 10 anos, onde nós brincávamos pequeninos. E além de tudo isso, ali podia-se lanchar, o 
que era muito importante para nós jovens que andávamos sempre esfomeados, numa época de racionamento alimentar.

Então, na Associação dos Escritores Moçambicanos encontrávamos toda aquela gente, tinha jovens um bocadinho mais velhos do que eu - como era o caso dos escritores jovens da Charrua, como o Eduardo White, o Nataniel Ngomane, o Khosa, o Jaime Santos etc. - mas que eram pessoas com quem a gente convivia todos os dias, que nos emprestavam livros, com quem discutíamos poesia e política. Bebia-se muito nessa altura. Era tudo muito efervescente, mas ainda muito livre, acho eu, nesses primeiros anos pós-independência. Ali na Associação não me lembro de alguém dizer: "tu não podes dizer isto" ou "não podes dizer aquilo". As pessoas diziam e escreviam aquilo que achavam, nas suas consciências, que podiam e queriam dizer e fazer. Se havia alguma censura talvez fosse mais uma autocensura, do que uma censura instituída.

Essa era a geração anterior à minha, mas não posso dizer nós os olhássemos como um modelo. Eu ia para a Associação quando eu tinha dezoito anos e estava ali com o Gulamo Khan que tinha trinta e tal, ou o Calane da Silva que tinha quarenta e tal e conversávamos todos juntos. Não havia separação de faixas etárias, como hoje: os kotas [mais velhos] e os jovens. E quando eu entrei no Instituto de Cinema era a mesma coisa. Essa separação geracional não se sentia, de facto. $E$ nesse tempo de revolução a gente começava a ser adulto muito cedo. Uma pessoa de quinze anos era tida como adulto e não havia ninguém que dissesse "tu não podes fazer isso porque só porque tens quinze anos". Ao contrário, eram-nos entregues tarefas de adulto e nós queríamos crescer rápido, aprender tudo o que pudéssemos para poder executar bem essas tarefas. Só para teres uma ideia, com quinze anos eu dava aulas de recuperação à quinta classe, a alunos de dez e onze, dava alfabetização a pessoas adultas no meu bairro. E já tinha trabaIhado durante as Atividades de Férias dos anos anteriores na fábrica de fósforos, na fábrica de cerveja, num Centro de Saúde para tuberculosos.

V. A.: O cinema brasileiro, assim como o moçambicano, enfrenta diversos problemas estruturais. Um dos problemas principais, é que nossas salas estão invadidas de filmes produzidos por uma poderosíssima indústria cultural estrangeira, que representa uma concorrência injusta à produção nacional. A própria produção nacional, por exemplo, pode ser dividida entre aquela que se volta unicamente para a indústria do entretenimento, e aquela que teria mais a ver com um "ci- 
nema arte", por assim dizer, que é o espaço da experimentação, da vanguarda e de linguagens mais complexas. Como essas questões acerca da indústria cultural e cinema arte se equacionam em Moçambique? É possível falar de indústria de entretenimento e cinema de arte em Moçambique? Como você situaria sua obra em relação a essas dinâmicas?

I. N.: Falar de indústria cultural em Moçambique é um perfeito absurdo. Não existe indústria cinematográfica absolutamente nenhuma. Indústria cinematográfica pressupõe a produção de filmes em quantidade suficiente para se dizer que existe uma cinematografia nacional, dinheiro para produzir esses filmes, equipamento à disposição, cinemas para exibir aquilo que se faz, distribuidores colocando os filmes nas salas de cinema e televisões nacionais e internacionais, leis que protejam, promovam e incentivem o cinema nacional e um lucro de biIheteira suficiente para subsidiar novos projetos. Ou seja, pressupõe a existência de toda uma máquina que no fim do percurso do filme, é rentável. Isso em Moçambique é uma mentira. É uma falácia. E uma falácia muito perigosa. Porque em cima dessa falácia se constroem políticas que deslegitimam o que nós fazemos, o pouco que se faz: porque não é rentável, porque não dá dinheiro, porque não é comercial etc. Eu creio que é um equívoco. Os poucos países africanos que dizem que têm uma indústria cultural - e dá-se sempre o exemplo da Nigéria vai ver a qualidade desses tais filmes de Nollywood... É claro que no meio de mil filmes há de haver alguns que tenham valor, que tragam alguma discussão sobre o que se passa no país, alguma reflexão sobre aquela realidade. Mas a maior parte são compilações patéticas de histórias americanas e indianas, feitas em condições completamente incríveis. Sim, tens quantidade. Mas o que é que está lá dentro? O que estás a disseminar como ideia tanto do que é cinema, como do que é arte, como do que é o teu país, como do que são as narrativas que fazem parte da tua história? Nada! É plástico, aquilo! E eu acho inacreditável que se pense nisso como modelo. A não ser que seja isso de facto que se pretende, esvaziar os filmes africanos do seu conteúdo histórico, cultural, político, social - o que faz algum sentido, numa lógica capitalista hegemónica...

Mas existem também modelos interessantes, modelos sérios. Por exemplo, a Zâmbia, é um modelo sério, que decidiu, num determinado momento - não há muito tempo - ter uma política de investimento no cinema como patrimônio histórico e cultural. Aí, sim, se tu tens toda uma política que fomenta a produção, que põe à disposição salas de cinema para exibir os filmes, que tem políticas 
de distribuição dos filmes dentro do país e fora do país. Tens o caso da África do Sul, que tem financiado fortemente o cinema, com imenso sucesso. Tens o caso do próprio Brasil - a lei de incentivo ao cinema no Brasil, na altura em que apareceu (não sei como está a funcionar agora) foi uma das coisas mais exemplares. Nós acompanhamos, por exemplo, o processo de um projeto aqui no Brasil que se chamava Cinema em Movimento e, em cinco anos, eles tinham conseguido levar cinema brasileiro, nos meios rurais e nos pontos de cultura, a um milhão de pessoas! Esses são só alguns exemplos de políticas consistentes de cinema que existem no sul. Se Moçambique quisesse pensar numa política séria para cinema, tinha modelos, não para aplicar taxativamente, mas em que nós podíamos nos inspirar, pensar em cima e criar um modelo que fosse adequado à nossa realidade. Mas não interessa. Porque não interessa o tipo de reflexão que o cinema conduz as pessoas a fazerem sobre sua própria realidade e, implicitamente, desperta um sentimento de necessidade de mudança. E nós - a maior parte dos cineastas moçambicanos - não queremos produzir filmes comerciais. Queremos produzir filmes que façam as pessoas pensarem-se a si mesmas e pensarem o seu país. É isso que nós fazemos. Há pessoas a quem às vezes mostramos os nossos filmes e dizem: "é difícil a gente compreender" ou "esses vossos filmes são feitos para serem vistos por vocês mesmos em Moçambique". Sim! Nós não temos qualquer pretensão - ou, só temos muito secundariamente essa pretensão - de exibir filmes em festivais. Nós queremos que estes filmes desempenhem um papel dentro do nosso país. É para isso que a gente os faz.

Então, tudo isso da indústria cultural, da indústria do cinema, é uma falácia para esconder a falta de vontade política de apoiar o cinema que, de facto, os moçambicanos querem ver. Nós temos na Associação de Cineastas um sistema de cinema móvel que se chama Cinema Arena, financiado pela Cooperação Italiana e nós levamos os nossos filmes a qualquer lugar do país, ao campo, às escolas e municípios mais distantes da capital. É inacreditável a reação das pessoas e a maneira como as pessoas se reveem nesses filmes! Não há nenhum filme americano aonde as pessoas vão, reajam e se comportem como com os filmes moçambicanos. Isso significa que as pessoas querem ver-se refletidas no seu próprio cinema. Não querem lá apenas rir de coisas que nem entendem direito e que são tão distantes, essas realidades tão diferentes, essas línguas, essa cultura. Se for possível ir lá rir e ver-se a si mesmo, e pensar nas suas coisas junto, tudo bem! Mas não é esse produto comercial que interessa às pessoas efetiva- 
mente. Estes filmes que a gente faz, sejam documentários, ficção, animação, interessam às pessoas, as pessoas gostam, comentam, discutem, têm sempre algo a dizer sobre a relação do filme com a sua realidade!

Eu passei, por exemplo, o filme do Malangatana [Ngwenya, o crocodilo, 2007] em Matalana, no dia que o Malangatana morreu. A projeção era ao ar livre, num descampado e veio a população inteira de Matalana para ver, ficaram noventa minutos a assistir, à noite, debaixo de chuva e no inverno: ninguém saiu dali! Por que? Porque estávamos a falar de um filho daquela aldeia, não estávamos a falar de outra coisa qualquer. Então essa coisa de virar a câmera para nós mesmos, que foi a opção que nós tomámos desde o princípio, acho que está certa. Não só é legítima e culturalmente importante, como tem um reconhecimento das pessoas, do público.

V. A.: Por mais de uma vez temos a oportunidade de ver pessoas que iniciaram suas atividades naquela geração dos anos de 1980 afirmarem que todos sonhavam com a construção de um "país diferente" em Moçambique. O que isso significava, e qual a dimensão desse sonho? Como o cinema se integrava a essa intenção de construir o país diferente? Este país se construiu? Se sim, como, e se não, por quê?

I. N.: O sonho... A grande questão que muitas vezes a gente hoje se coloca é: se esse sonho de fato era genuíno ou se era apenas um discurso, uma falácia. Muitas vezes, como tu dizes, lá em Moçambique se coloca isso, há uma tendência de se dizer que os dirigentes - que são praticamente os mesmos dessa época até hoje - nunca estiveram de boa-fé, que a revolução nunca foi uma coisa realmente genuína, que usaram esse discurso socialista para agregar e fazer com que as pessoas acreditassem numa coisa que eles já sabiam que falharia, que nacionalizaram com a intenção de depois privatizar em proveito próprio... Eu não creio, não creio...

Eu creio que houve realmente um sonho, que esse sonho foi partilhado, que esse sonho foi acolhido e vivido pela grande maioria dos moçambicanos. Eu não posso dizer por todos, claro que há exceções, mas o sonho de independência, o sonho de construção de um país diferente, mais justo, mais livre, soberano, alguma espécie de terceira via que conseguisse não ser enfeudada à União Soviética, mas que também não se vendesse ao capitalismo, acredito que era genuíno. Havia toda a fantasia dos "não-alinhados", havia toda a questão da "linha-da- 
-frente", havia todo esse enquadramento político. E, por outro lado, era muito claro que, para construir esse sonho, tínhamos que prescindir da individualidade em função do coletivo. Isso foi muito claro desde o início. E isso era um problema. Para mim isso era um problema, desde sempre.

Eu lembro-me de quando comecei a viver esse conflito, junto com meu próprio conflito identitário normal da adolescência. Tinha uns treze anos, talvez quatorze, não sei, quando eu passei um dia numa pequena papelaria e vi na montra um livro que tinha uma capa amarela com letras castanhas que dizia: Tornar-se pessoa. Eu olhei para aquilo e disse: "que maravilha! Ali deve estar a solução! Ali deve estar uma espécie de uma receita de como é que eu vou fazer para me tornar pessoa no meio disto tudo!" Porque é tão difícil de explicares a si mesmo essas passagens históricas sendo criança, pré-adolescente, quando tu estás a construir-te como pessoa e todo aquele mundo se desmorona... Eu vivia num bairro - a Polana - onde, todas as pessoas que habitavam ali, aquela famílias portuguesas todas, foram embora, ficaram duas, três famílias. Três famílias, num bairro inteiro! Um bairro que tinha centenas de casas! E isso tem alguma coisa de assustador: de repente, as casas ficam vazias, de repente a gente - as crianças que restávamos - começa a brincar dentro de casas desertas, a abrir armários e encontrar roupas, encontrar coisas de pessoas que sumiram, de crianças que eram nossas amigas. Há uma zona ali de vazio e de tensão, tu não sabes o que vai acontecer a seguir. Isso foi entre 1975 e 1976, imediatamente após a independência, sobretudo quando começou todo o movimento das nacionalizações, quando os portugueses saíram em massa. Na escola era a mesma coisa, a minha turma ficou com seis pessoas! Éramos quarenta, ficámos seis! Nós tínhamos aulas numa mesa, o professor sentava-se ali e nós os seis, sentávamos aqui, porque não fazia sentido estar em uma sala de aula vazia doutra maneira.

Então, no final de 1976 - já depois das nacionalizações - começam a chegar novos habitantes ao meu bairro, começam a chegar novos alunos à escola, vindos das escolas da periferia, pessoas que moravam nos subúrbios passam a habitar a cidade. Foi um período meio complicado esse do pós-independência, porque se tratou de uma descolonização radical, e no meio disso tu estás a crescer, mas tu não podes falar de quem és, tu não podes dizer de onde é que tu vens, tu não podes dizer o que faziam os teus pais, tu não tens a cor certa, tu não estás no lugar certo, tu és descendente de colonos (colonialistas, como diziam na altura). Quer dizer, fica tudo em suspensão, é um outro período de suspensão de tudo, 
não é?

Então, é como se tu vivesses o teu crescimento em suspensão da tua pessoa. Tu não podes ser. Então quando eu vejo aquele livro que diz na capa Tornar-se pessoa, eu digo: "é isso! Ali está a solução!". Então começo a juntar dinheiro, dinheiro dos lanches da escola e tal, para comprar aquele livro. Para conseguir comprar aquele livro, eu montei até uma papelaria na minha própria casa, construí umas estantes com madeiras - havia muitos caixotes, restos de contentores de madeira das pessoas que estavam a ir embora do país. Então, com isso fiz eu mesma uma estante, preguei as tábuas, pintei de amarelo, pus na varanda da minha casa e vendia cadernos, canetas, borrachas e lápis etc. aos meus irmãos e às crianças da vizinhança, para conseguir juntar mais um dinheiro para conseguir comprar mais rapidamente aquele livro. Eu queria aquele livro, queria muito, queria mesmo! Achava que aquilo era uma espécie de uma Bíblia, numa época em que já ninguém lia a Bíblia.

E lá fui eu, ao fim de três meses, comprar o livro. Era um livro do Carl Rogers. Abri, li as primeiras páginas, mas eu não consegui entender nada (risos)! Foi uma tremenda decepção! A gente ficava à procura de coisas quase que um pouco mágicas, que nos tirassem daquele estado de suspensão e que nos dessem alguma espécie de direção para a gente ir, porque além de tudo o mais, em termos familiares, também estava tudo um caos. O meu pai ficou completamente deprimido na altura das nacionalizações porque perdeu tudo o que ele tinha construído ao longo de 50 anos de trabalho como médico, como casas. Tinha setenta e cinco anos em 1975 e queria ir embora para Portugal. Mas minha mãe não queria, ela era uma pessoa mais de esquerda e desapareceu, imbuída nas tarefas da revolução. Passou a ser diretora pedagógica do Ministério da Saúde, responsável por elaborar os currículos de todos os cursos de saúde, de parteiras, auxiliares de saúde, enfermeiros, técnicos de laboratórios, técnicos de saúde, porque o Sistema de Saúde ficou sem ninguém, os portugueses que trabalhavam nesses postos todos foram embora e era preciso urgentemente formar novos quadros. E ela saía de manhã, às seis e meia da manhã e só voltava lá para as nove ou dez da noite, a gente já quase não a via.

Éramos cinco irmãos, a mais pequenina tinha quatro anos na altura da independência e o mais velho tinha onze, eu era a segunda, tinha dez, depois vinha uma irmã de nove e um de oito. Ficávamos atirados no meio daquilo. E eu sentia-me responsável por todos eles, incluindo o mais velho. Então, se alguém dissesse 
assim: "olha, vem aqui que eu te digo o que é que tens que fazer com tua vida", eu ia imediatamente. Mas não tinha ninguém para dizer isso. $\mathrm{E}$ a gente vivia procurando sinais, procurando coisas que nos indicassem por onde ir. Houve, por exemplo, uma figura que foi fundamental nessa altura da minha vida, que se chamava Maria Inês Nogueira da Costa, uma historiadora maravilhosa, que foi diretora do Arquivo Histórico durante décadas. Nessa altura, ela era minha professora de História da 60 classe e era a única pessoa que nos explicava o que estava a acontecer, nas aulas. Porque a História estava ali. Claro que ela falava do Império de Muenemutapa e coisas assim, mas dizia-nos todos os dias que a História era aquilo que estávamos a viver: a passagem do colonialismo a um país independente.

Eu nem posso dizer que a gente sonhou o sonho. Nós éramos parte do sonho. Eu acho que o sonho e o sonhador são a mesma coisa, o sonho está dentro do sonhador quando ele o sonha. Ele não vai buscar o sonho lá fora. O sonho é parte dele, simplesmente, quando ele está a dormir, vê-o de outra maneira. Ele aparece com outra forma, noutros termos, com outra linguagem. Então, a gente estava a sonhar o sonho, nós éramos os sonhadores e éramos parte do sonho. E o sonho também era de que nós fôssemos parte desse sonho de forma mais ativa quando fôssemos adultos. Mas a um certo momento, a gente começa a perceber que é obrigatório continuar a sonhar, já não é exatamente o nosso e não sabemos se nós devemos ou queremos continuar a ser sonhadores desse sonho. É quando a coisa se começa a clivar e eu começo a entender que a equação não é tão simples: eu não conseguia prescindir da minha pessoa e eu não tinha sido educada de forma a ser obediente, a seguir regras sem as entender, a fazer coisas que não me fizessem sentido, eu sempre fui educada exatamente ao contrário de tudo isso. Aprendi a ser responsável, mas a partir de uma ética interiorizada, a partir de um assumir de coisas que fizessem um sentido a nível muito profundo. Então, era uma coisa que não cabia, essa filosofia da obediência cega e da disciplina surda, não cabia na minha pessoa, nem dentro do esquema filosófico em que eu fui criada e educada. E rapidamente, essa clivagem se começou a fazer.

Isso tudo fica ainda mais complicado mais tarde, quando entramos no período da guerra. Eu vou para o Instituto de Cinema e vou filmar a guerra e aí começo a deparar-me com essas questões, de um lado e de outro lado. O autoritarismo do poder da FRELIMO versus aquele universo de atrocidades inconcebíveis feitas 
pela RENAMO. Entre o autoritarismo e aqueles massacres que eu via e filmava, era preciso tomar uma posição, como em todas as guerras, não se pode ficar no meio. Quer dizer, tu até podes ficar no meio, no sentido de filmar tudo o que acontecer, de assistir, de reservar para a História o direito de fazer o seu julgamento, mas no momento em que tu estás a fazer as coisas, tu não consegues ficar isento. Tu não consegues filmar um massacre e dizer: "bom, a RENAMO é um movimento que está a lutar pela democracia e este é o meio de chegar à democracia!". Não é assim que se passa. São coisas muito terríveis e que geram... eu nem posso dizer que geram raiva, revolta, pois isso são palavras muito banais, muito pouco fortes para dizer aquilo que eu senti quando eu olhei para essas coisas! De tal forma, que são coisas das quais, a maior parte, eu nem me consigo lembrar...

Eu não tenho memória da maior parte das coisas que eu filmei durante a guerra. Eu via-as uma vez, quando aconteceram - e quando aconteceram nem sei se eu vi, ou se eu vi só atrás da câmara, que não é exatamente a mesma coisa que ver - ou se eu vi sem ver exatamente. Vi-as mais uma vez quando estava na mesa de montagem - eu é que dirigi a montagem, escolhi as imagens - e depois vi a cópia 0 , projetada para aprovação. Portanto, eu vi essas imagens pelo menos três vezes e eu não guardo qualquer memória delas. Alguma coisa de muito complicado se passa quando enfrentas essas coisas. Não é possível tu veres e conseguires digerir. Eu tinha dezenove ou vinte anos nessa altura, quando comecei a filmar essas coisas. Então, é claro que o sonho já não é mais sonhável da mesma maneira. Aquilo começa a ficar muito difícil de sonhar.

E, do lado em que tu estás - que te parece na altura o único possível - tu vais percebendo que o autoritarismo começa a ser cada vez maior, as coisas começam a ser cada vez mais difíceis e cada vez mais estritas, que tu tens cada vez menos espaço para dizer as coisas como tu queres dizer. E começas a assistir do lado de cá, também, a coisas terríveis: Campos de Reeducação, Operação Produção, fuzilamentos sumários, leis de pena de morte, chicotada em praça pública, recrutamento compulsivo para o Serviço Militar Obrigatório. Começas a perceber os excessos desse poder também e tu começas a te deslocar para o meio e a ficar numa posição em que dizes: "eu vou filmar tudo, vou filmar tudo que eles fizerem, tudo que os outros fizerem e, à frente, pelo menos está registrado, pelo menos não se pode dizer que não aconteceu, não podem dizer que não fuzilaram essa pessoa, não podem dizer que essa pessoa desapareceu sem 
se saber para onde, pois está aqui, impresso na película!" E são esses os arquivos a que hoje nós não temos mais acesso.

Para mim essa fase termina no dia em que o Samora Machel morre. No dia em que eu chego no Instituto de Cinema e dizem "o avião do Samora caiu", eu não consegui sequer processar. É uma coisa tão absurda, que leva muito tempo a tu processares. Começo a processar quando vamos para o aeroporto, filmar a chegada dos corpos dentro dos sacos plásticos, quando vamos para a morgue filmar os corpos a serem tirados dos sacos plásticos, incluindo os dos nossos amigos, nossos colegas, que iam junto, no avião. Quando tu te confrontas com a imagem, é que tu percebes o que aquilo significa. E quando nós filmamos, três dias depois, o funeral do Samora, quando a gente começa a andar pelas ruas com o cortejo do Samora e começamos a ver a reação das pessoas, a dor das pessoas. Era como se tivesse morrido uma pessoa da família delas, como se tivesse morrido um filho, uma coisa assim mesmo que saiu de ti. Aquelas pessoas não estavam a chorar um presidente, estavam a chorar alguém muito próximo e muito querido. E quando eu faço essa passagem, esse longíssimo travelling de rostos de homens chorando em silêncio, segurando a cabeça em desespero, de mulheres em pranto, quando filmo isso, eu percebi que aquela revolução acabava ali! Dali para frente ia ser outra coisa.

E de fato, pouco depois filmei a primeira viagem do presidente [Joaquim] Chissano, fui com ele, através do país, filmar sua primeira visita às províncias, aos distritos e já era outra coisa, já estávamos em outra era. E era absolutamente claro o que é que vinha a seguir, eu não tinha nenhuma dúvida. Eu já sabia que o que ia vir a seguir era o que estamos a assistir desde então até agora. Claro que eu não imaginava que seria de uma forma tão despudorada e com tanta impunidade, com tanta falta de escrúpulos, mas só nos surpreendeu em termos de quantidade e não em termos de qualidade.

É evidente que fomos educados dentro da ideologia do sistema socialista. Mas se tu perguntares às pessoas de minha geração, eles sentem-se, a maior parte, traídos na sua entrega a essa revolução, porque se entregaram, tinham que se entregar. Mas acho que há muito poucas pessoas da minha geração que possam dizer que preferiam ter vivido outra juventude, outra adolescência que não essa. E eu acho que a gente viveu e teve o imenso privilégio de viver uma época histórica atravessada por três épocas. É uma experiência existencial assim incrível, incrível. Eu não gostaria nada que os meus pais tivessem tomado a decisão de 
ir embora para Portugal, eu não seria a pessoa que eu sou hoje. Eu seria outra coisa, melhor ou pior. Mas eu gosto muito de ser quem eu sou, com toda essa história e com toda essa vivência. Acho que é uma riqueza enorme, acho que eu vivi imenso numa vida só. Tenho cinquenta anos, mas às vezes sinto que eu tenho cem, que vivi imenso, acho que posso narrar e contar histórias ininterruptamente durante mais cinquenta anos!

V. A.: Ao pensar nas questões etnoculturais de Moçambique, somos levados a refletir a respeito do difícil problema da cidadania das diversas culturas que se encontram naquele espaço. Negadas durante o tempo colonial pelo eurocentrismo racista, negadas no pós-independência pelo temor ao tribalismo e ao obscurantismo, como percebe o estatuto social e civil dessas diferentes pertenças hoje em dia? De que forma seu trabalho se articula com essa problemática?

I. N.: Olha, eu acho que há duas coisas em relação a essa diversidade. A primeira, tem a ver um pouco com o fato da minha própria identidade cultural. Minha mãe era portuguesa de origem e meu pai era goês. Embora eu tenha crescido parcialmente em meio a cultura ronga dentro de minha casa, não é a minha cultura de origem. Mas essa vivência múltipla faz com que eu tenha uma curiosidade maior, pois eu sou um pouco o Outro. Eu tenho realmente uma vontade imensa de conhecer melhor todas as culturas, dentro de suas especificidades. Eu gosto desse trabalho etnográfico, digamos assim. Tenho vontade de estar lá no campo, de me sentar com as pessoas, de conhecer melhor cada pessoa, escutar o seu conhecimento. E as pessoas são compostas desses cruzamentos de valores e significados que se tu não conheces, não podes partilhar. O Mia Couto disse uma coisa muito bonita para o filme do Malangatana, que essa questão da moçambicanidade é uma viagem, um processo de construção de ti mesmo ao longo da tua vida no contato com tudo quanto compõe o teu país. Esse país que não existe, esse país que se está a fazer, essa nação que está a ser inventada; essa nação que é um conceito político que foi cunhado na independência, mas que é uma construção, uma utopia, se quisermos chamar assim. E que vai levar muito tempo, talvez séculos, para que essa construção se faça ao nível vosso [dos brasileiros], pois nenhum de vocês tem dúvidas de que é brasileiro e de que outro, mesmo sendo diverso de ti, é brasileiro também. Mas esse conceito de "brasilidade" levou séculos a se construir, e certamente não era assim, há duzentos anos atrás. 
Então, a minha busca é de conhecer essa nossa moçambicanidade em suas múltiplas riquezas. E é uma riqueza completamente inacreditável, eu vivo num lugar em que atravesso os $2500 \mathrm{~km}$ do país e tenho cinquenta culturas diferentes. Então, eu tenho o privilégio de me aproximar disso através de um instrumento que é o cinema, de recolher isso, de ajudar a preservar essa diversidade, essa unicidade, essa multiplicidade. Porque, com essa voragem capitalista selvagem, após o cilindro da globalização ter passado ali durante umas décadas, eu não sei o quanto disso ainda vai restar. Então, se eu posso registrar um pouco dessa riqueza, eu não vou deixar de fazer.

Mas isso é uma questão. A outra questão é uma questão de classe. Também, da mesma natureza, mas de classe. Eu cresci numa família basicamente humanista. Humanista um pouco católica, mas no espírito de minha mãe, da teologia de libertação. Então, sempre, na minha vida, se colocou essa questão da diferença social. Durante a época da revolução, não vivemos mais dentro de uma sociedade de classes e talvez essa tenha sido a escola mais bonita que eu podia ter de como sermos todos iguais, prescindindo até de alguns privilégios que tínhamos anteriormente. Por isso eu tenho muita dificuldade em aceitar que dramas sociais sejam coisas inalteráveis. Acredito que as desigualdades existem porque existe uma profunda injustiça na distribuição dos recursos e das oportunidades. E aí, talvez, é onde eu seja mais politicamente empenhada. Se a nossa revolução tivesse vingado e tivéssemos construído um país mais justo, mais igualitário, um Estado mais social - como ele deve ser - eu seria uma pessoa mais feliz. Se eu pudesse viver um pouco mais essa utopia de criar essa sociedade mais justa, mais igualitária, eu seria mais feliz. Então, eu tento fazer ainda hoje com o meu cinema um pouco disso: trazer as problemáticas atuais, com o sentido de mostrar que elas têm de ser resolvidas. Não no sentido de mostrar que há ali um drama inevitável, "coitadinhas das pessoas", não! Trato todas as pessoas como sujeitos da sua história, como personagens de si mesmos. Daí a forma específica como eu trabalho o cinema. Quando tu colocas alguém no centro do olhar e tu Ihe dás a oportunidade de se apresentar como uma personagem ao Outro - ao Outro da câmara, ao Outro do realizador, ao Outro do público, aos Outros da sua comunidade que o vão ver na televisão; quando tu abres, com o filme, a oportunidade de um sujeito se tornar personagem, ele nunca mais vai deixar de ser um sujeito. E nunca mais vai deixar de olhar para si como uma pessoa que existe no mundo. Eu existo! Eu não sou invisível, eu não sou um número, eu não sou 
um pobre: eu sou eu! E talvez isso tenha a ver com a minha história, com a dificuldade que eu tive de ser eu, e de me posicionar como sujeito dentro daquele contexto histórico em que eu vivi. E talvez baste essa vírgula na vida de alguém, uma vírgula tão constituinte, que uma série de coisas mudam!

De todo modo, é importante dizer que em Moçambique, há tabus. O tribalismo foi e é um tabu. O racismo é e foi outro tabu. São coisas que nunca se abordam. Fala-se de raça agora em termos essencialistas, descriminando "originários" e "não-originários", porque esse discurso serve a certos interesses de classe, mascara diferenças políticas. Mas não se chama a isso racismo, tu não podes em lugar nenhum queixar-te de que estás a ser racialmente discriminado no teu próprio país, além da Constituição, que diz que somos todos iguais, não existem leis que condenem a descriminação racial. Também não se pode falar de "tribo", não se fala de diferenças étnicas, também não se fala de diferenças linguísticas, políticas, sociais, culturais como constituintes da nossa moçambicanidade. Não se procura preservar e manter vivas as especificidades culturais porque, se tu cuidas da cultura das pessoas, estás a empoderá-las naquilo que elas próprias são, na sua unicidade, na sua diferença, quando todo o processo até aqui teve como objetivo destituí-las dessa identidade, para que ela fosse aplastada no nível identitário da nação. Para que pudesse aparecer a nação, essa grande utopia, que agora cada vez menos se faz presente no nosso quotidiano de cidadãos, engolida na voragem capitalista globalizante.

E foi assim que todos nós, cidadãos moçambicanos, vivemos a nossa trajetória pessoal, familiar, grupal, ao longo das várias épocas históricas, políticas e económicas que o nosso país atravessou. Em cada uma delas, de diferentes maneiras, fomos aprendendo a silenciar a nossa identidade e ao mesmo tempo, a lutar no pouco espaço que conseguimos encontrar, com os meios, as formas, as linguagens que conseguimos inventar, para não desistirmos de ser quem nós mesmos somos. 


\section{ELIKIA MBOKOLO}

IA ATLÂNTICA: Como foi sua iniciação e formação no campo da História?

ELIKIA M'BOKOLO: Já na minha infância, estudei história em Lingala. Tivemos um professor de História congolês que tinha um grande background: nos falava do encontro entre o Nzinga Vemba e o Diogo Cão, etc. Eu, naquelas alturas devia ter 7 ou 8 anos de idade. Fez-me uma grande impressão em saber que no final do século XV a África Central já tinha Estados, civilizações, cidade e línguas. Quando os portugueses chegaram aqui já havia uma civilização e isso impressionou-me, pois tínhamos uma civilização há cinco séculos e agora éramos colonizados. Creio que este pormenor foi esquecido por mim, mas que mais tarde veio-me a memória. Depois surgiu então o período da descolonização, surgiu-me a questão em saber se foram os belgas que estavam a proporcionar a descolonização, ou eram os próprios congoleses que fizeram por conquistar à luta para descolonização. A ideia que reinava, pelo menos no seio da minha família, é que fomos nós que ganhamos a luta. Eu fui estudar para França, me tornei num estudante muito bom. No entanto, não sabia de fato o que havia de seguir em termos de percurso acadêmico. Fiz uma licenciatura em Letras Clássicas, em língua latina e francesa, mas não quis continuar nas Letras, porque, naquela altura, a visão da juventude africana daquela época em relação às pessoas com um diploma das Letras era de um potencial candidato à repetição das teses defendidas por Leopold Senghor, no Senegal. Senghor, para nós, não passava de uma cópia negra dos brancos. Portanto, deixei a literatura. Quanto ao Direito, deixei de ter qualquer simpatia por esta disciplina pelo fato deles serem muito práticos em detrimento da teoria, porque preocupam-se mais com o Direito disto e daquilo, explicações daquilo etc. Eu não queria ficar só com a componente prática, queria outra coisa.

Ainda tive o privilégio de estudar filosofia, já que consegui entrar na Escola Normal Superior (École Normale Supérieure, de Paris), que é uma escola muito difícil de se entrar. Tive o grato prazer de ter professores renomados nas áreas de filosofia e psicanálise. Depois decidi ir paras as ciências sociais, antropologia e etnologia, que me pareciam ciências coloniais. Acabei por optar, então, pela História, porque em França, a História é uma disciplina muito importante: a identidade 
francesa, passa pela História. Foi assim que comecei a estudar História de África, numa visão que combinava a exigência e a mais alta qualidade, em que se podiam discutir às fontes, os trabalhos e a problemática, a visão de longa duração e que não fosse uma visão sentimental. Por exemplo, a visão do Cheikh Anta Diop, era uma visão muito interessante, mas estava mais baseada nos sentimentos, em prejuízo das pesquisas. Eu queria uma visão mais técnica e que não fosse frágil neste sentido, uma visão de longa duração. Essa parecia, de fato, a visão do Nkrumah e outros. Foi aí que passei a ser cada vez mais exigente comigo mesmo. Quando terminei a minha formação, procurei, regressar a Kinshasa, [para me candidatar] a Universidade Católica de Lovaina (Université Catholique de Louvain), que era católica. Eles não gostaram da ideia de fazer o recrutamento de alguém que vinha de França, um país laico. Eles não queriam me recrutar, e fiquei lá sem trabalhar. Foi assim que a minha universidade em França, depois de se aperceber do que estava a acontecer, disseram-me: "se você não tem trabalho aí, nós podemos arranjar aqui". Foi assim que eu aderi até hoje.

V.A.: O senhor diz que Senghor matou alguns bons quadros africanos, quando ele pelo menos teve o condão de ter conseguido coabitar com os seus opositores, por exemplo, o Cheikh Anta Diop. Não Ihe parece que há alguma contrariedade nisso?

E.M.: Penso que não, porque o Cheikh Anta Diop continuou a fazer o seu trabalho, mas nunca chegou a ser professor na Universidade de Dakar. Ele foi um pesquisador do Instituto Fundamental de África Negra, e nunca conseguiu estar numa posição em que realmente pudesse fazer a divulgação e discussão das suas pesquisas na academia. Ficava fechado no seu laboratório sozinho, sem qualquer abertura. Os jovens que tentaram romper a barreira da universidade em direção à sociedade, foram mortos. É por isso que Senghor, ao menos para mim, era mais um francês do que um africano.

Quem de fato foi africano foi o Mamadou Dia. As pessoas já não se lembram que independência do Senegal se deveu muito ao Mamadou Dia. A independência não foi propriamente um mérito do Senghor, porque o Senghor quis continuar na República Francesa. Dia foi acusado de organizar um golpe de Estado entre 1961 ou 62, que não foi propriamente um golpe de Estado, o que Ihe custou uma cadeia por mais de vinte anos. Por esta razão eu não tenho qualquer tipo de simpatia pelo Senghor, porque ele não fez absolutamente nada para mudar a 
situação da sua terra. A diplomacia senegalesa continuava a ser controlada pela França, a economia continuava a ser francesa, no capítulo da cultura, Senghor continuava a falar da negritude, mas não gostava de Franz Fanon. Foi amigo do Aimé Cesaire, nunca permitiu que ele fosse ao Senegal para apresentar algumas palestras. Senghor foi, sem dúvidas, muito inteligente, mas para mim, nunca foi um bom exemplo de um político africano.

\section{V.A.: Em que aspectos discordava de Cheikh Anta Diop?}

E.M.: Do meu ponto de vista, está no tratamento das fontes. Isso para um historiador é um aspecto muito importante. Diop trata das fontes secundárias, ou seja, não é ele que vai ao encontro das fontes, não é ele que mergulha na tradução, o que tem de ser muito importante. Porque um texto escrito na língua grega, por exemplo, deve-se ter cuidado com a forma que foi traduzido e escrito. Não é o caso dele, que se baseou na tradução dos outros. Eu gosto que seja exigente em tudo, e não que seja parcialmente exigente. Cheikh A. Diop teve este cuidado com algumas fontes e não com todas. A minha crítica não recai apenas ao Diop, mas tem incidência sobre os seus discípulos, porque continuam a reproduzir as suas teses, o que não ajuda na evolução do conhecimento.

Este é um aspecto. O outro, tem que ver com o conhecimento. É sabido que África é a mãe das civilizações, mas o que se pretende é explicar a nossa situação atual, num tempo de longa duração. Quais são as roturas / rupturas que ajudam a explicar a nossa situação hoje? Diop é um pesquisador que todos reconhecemos a envergadura. Creio que ele próprio gostou da discussão que teve comigo, e concordamos sobre este aspecto. Para mim, as roturas me parecem mais importante que as continuidades de suas teses. Ele defendia que África precisa somente voltar aos valores do passado, mas quais foram as roturas e como é que vamos fazer para voltar? É só voltar? Eu não estou de acordo com esta forma de ver, temos que recuperar as roturas e reinventar a cultura na atual situação e ter uma visão para o futuro.

V.A.: Senghor defendia a tese de que em África não é curial falar de estrato social, não na perspectiva de Webber e Marx, que para o caso africano deve-se falar de estratificação, na medida de perspectiva etnicista...

E.M.: Depende dos períodos. Porque nos tempos mais recuados, é verdade que havia uma maior proximidade e uma mobilidade importantes. Acho que então 
o parentesco era mais importante que a estratificação rígida. Mas depois deu-se as roturas, com o chamado "tráfico negreiro", com as deportações dos africanos, o colonialismo e o islamismo, que introduziram diferenças que foram muito importantes nas sociedades africanas. Pessoalmente, eu não acredito nas teses que diziam ser suficiente organizar as sociedades com base nestes valores culturais e tradicionais, que foram defendidas pelo Senghor e Julius Nyerere na Tanzânia. Senghor nem sequer conseguiu organizar a sociedade senegalesa, porque não passava de uma perspectiva utópica, ou seja, eram mais discursos que não tinham implementação prática.

V.A.: Que apreciação faz da tese do Cheikh Anta Diop sobre o federalismo africano?

E.M.: Sabemos que as fronteiras africanas são superficiais e que se pode organizar outras formas de territorialização e organização espacial. A dificuldade está na posição das lideranças políticas, que precisam lidar com a organização patrimonial. Esse é o principal obstáculo para unidade do continente. Sem esquecer dos interesses ocidentais e até mesmo da China. Estes precisam que a África se mantenha assim, porque facilita o seu projeto de exploração do continente.

V.A.: Por que que os franceses ainda têm dificuldade em reconhecer a contribuição do Cheikh Anta Diop? Facilmente encontramos estudos sobre Senghor em França, há homenagem, espaços académicos com seu nome, e não do Cheikh Anta Diop, quando este terá sido dos mais brilhantes pesquisadores do continente?

E.M.: Sim, isso é evidente. Se reparar, quando o presidente francês foi a Dakar para fazer uma oração de sapiência em 2007, ele disse: "eu estou aqui na Universidade de Dakar", quando já não era Universidade de Dakar, mas sim Universidade Cheikh Anta Diop. Ainda é uma pessoa de quem eles não gostam, e não reconhecem como pesquisador de alto nível. O que quer dizer que a rotura iniciada pelo Cheikh Anta Diop deve continuar e ser aprofundada, para que se possa romper com este paradigma ocidental, no sentido de criarmos um paradigma africano.

V.A.: Qual tem sido, hoje, o papel das elites africanas: a intelectual, a religiosa e a política? 
E.M.: Temos uma elite política que se posiciona só em relação ao poder, para si próprio, que não tem realmente uma visão para o futuro de longa duração e para o povo. As elites estão numa situação de acumulação, que não é em si má de todo, mas acumulam não para suas terras, mas para si próprios, para as suas mulheres, os seus filhos etc.

\section{V.A.: Não se pode falar aí de acumulação permissiva...}

E.M.: Não é acumulação permissiva, porque acumulação permissiva é a que permite que se vá para frente num período de longa duração. Neste caso, estamos a falar de uma acumulação de grande escala para si, esquecendo-se que há exemplos deste tipo de acumulação que não ajudou em nada ao continente, esquecem-se que quando a burguesia decide acumular, faz para terra, para produção fornecimento do trabalho para a gente e o dinheiro, nestes casos, fica fora do continente, este dinheiro contribui para riqueza dos outros e quando estes líderes africanos perdem o poder, os europeus arranjam formas ou criam processos jurídicos, para dizer que este dinheiro é ilícito acabando por conquistar o dinheiro, que é perfeitamente lamentável, este cenário acontece aos políticos. Quanto aos intelectuais, estes existem em África, mas sinceramente não sei o que se passa, o que se passa é que temos um déficit de produção de conceitos adaptados para África, produção de abordagens africanas e pensamento que podem ajudar na mudança do continente, são de fato produções mais teóricas do que práticas, estas debilidades fazem com que os intelectuais africanos e até mesmo nossas universidades pareçam não ajudar o continente. Já as elites religiosas estão mais comprometidas com a sociedade, estão à procura de alguma coisa que o continente pode oferecer, mas me parece que estão mais interessados em tratar dos casos individuais, do que da situação global do continente ou de cada um dos países.

V.A.: Há hoje uma discussão, sobretudo em França, dos chamados Estados neopatrimoniais. Há evidências, no caso africano, desse tipo de Estado?

E.M.: Sim, claro, os casos que ocorreram nos dois Congos, o que aconteceu no passado no Gabão, o caso do Togo, dos Camarões etc. São casos em que isso se evidencia. Mesmo no caso da África do Sul, quando olhamos para o clã Mandela, continuam a valorizar o patrimônio simbólico e até mesmo financeiro. Os casos dos dirigentes do ANC, por exemplo: é lamentável ver o que terá acontecido 
com eles. O caso do Cyril Ramaphosa, que foi um dirigente muito importante do ANC, hoje é bilionário, um indivíduo que não produz nada, como é possível isso acontecer? Por isso é que penso que a elite política está a se transformar numa elite econômica, sem produzir nem fazer acumulação patrimonial, que pode realmente ajudar a comparar a burguesia da Europa que fez este trabalho de casa. Por isso é que o continente não avança, continua inerte.

V.A.: Ainda sobre as elites intelectuais, há um déficit de leituras que se nota na juventude africana, ao lado do fato dessas sociedades serem muito movidas pela oralidade, por via das artes.

E.M.: Sei que há alguma intelectualidade na universidade e que estão a fornecer matéria para se andar para frente, mas não há hábitos de leituras e de compra de livros, hábito de estar em casa a ler estudar e discutir, por esta via. Se calhar teremos que combinar uma frente com os artistas, com escritores, músicos, romancistas, poetas para que possam aproveitar a sua condição de estarem mais próximos da população, e transformem as consciências pela porta das artes.

V.A.: Qual seria o papel da diáspora africana no sentido de ajudar a resgatar a matriz identitária dos africanos?

E.M.: Pode-se notar que hoje os chamados "afrodescendentes" que se encontram na América, nas Antilhas, na Europa e na Índia, são os conservadores de valores do continente africano, por via da religião, dos sentimentos de solidariedade, da visão do futuro, das resistências. Nas minhas aulas de história africana, no que diz respeito à diáspora africana, considero que a África de fora joga um papel muito importante para o interior do continente. Na década de 1950 e 1960, nota-se que a diáspora, de fora e a do interior do continente, tiveram uma forte ligação. Hoje fala-se muito do pastor Martín Luther King. Ele começou sua luta nos Estados Unidos mas terá sido convidado por Kwame Nkrumah para festa da independência do Gana. Depois de ter assistido aquele ato simbólico, disse: "acredito que os negros estão em condições de conquistar as suas independências e ganhar a luta contra os brancos. Quando eu regressar aos Estados Unidos, vou incentivar a luta", e o seu célebre discurso "I have a dream" tem tudo a ver com o que aconteceu no continente africano. Podes também utilizar os sucessos da diáspora para desenvolver o continente africano. 
V.A.: A história se repete, ou seja, o que aconteceu no passado, pode vir acontecer, quase que de forma cíclica...

E.M.: Sim, são processos cíclicos, mas que não ficam inertes são ciclos dinâmicos, e podemos avançar desta forma.

V.A.: Também se verifica hoje em África um problema, que é o da investigação científica. Há casos de Angola e Moçambique, por exemplo, com projetos que não avançam sem contar com apoio da Comunidade Internacional. Com essa fragilidade, e até porque quem dá a verba tem sempre algum interesse, como é que podemos sobreviver perante tal condição?

E.M.: Falou de Moçambique, estou a pensar no Centro de Estudos Africanos que foi muito importante, ligado à Universidade Eduardo Mondlane, que hoje não tem meios. O que precisamos hoje é ter em primeiro lugar, uma política científica. Quais são as prioridades? Com quem podemos contar? E procurar meios financeiros, porque precisamos de computadores, de livros, temos que ter condições de sobrevivência que possam permitir que estejamos somente empenhados na pesquisa. O contrário disto faz com que os pesquisadores percam a visibilidade social. Os jovens olham para eles, e dizem: "olha para este pesquisador, não tem meios de sobrevivência". Aí ficam cada vez mais isolados, sem conseguir cativar os jovens cadetes de investigação. Alguns dos poucos estão sem meios de sobrevivência para si e para a família. A questão do financiamento é, de fato, uma questão muito importante, e deve vir do Estado nacional e não de fora.

V.A.: Tendo em conta que as poucas pesquisas realizadas tenham sido suportadas pelas chancelarias internacionais, quais podem ser os riscos que se corre com este tipo de financiamento?

E.M.: Normalmente tem havido interesse em ditar agenda de pesquisa, com base nas suas prioridades. É uma forma de confiscar as pesquisas e o pensamento africano. Com isso, acabam por publicar as ideias principais que são nossas e nós nos tornamos meros consumidores, quando as ideias fundamentais eram nossas. Passam a ser deles por confisco, que publicam em livros que nós consumimos como se fossem eles os merecedores das pesquisas. É de fato uma situação perfeitamente lamentável. 
V.A.: É radicado em França. Que apreciação faz dos cursos de ciências políticas ministrados em França, com o percurso dos países africanos do Sul ("Politique et développement en Afrique et dans les pays du Sud", o PDPAS)?

E.M.: Para mim, tem havido uma contribuição que pretendem dar, por exemplo, na elaboração do conceito de neopatrimonialismo. Foi sem dúvida uma contribuição importante, mas em geral eles não têm conhecimentos suficientes sobre o que acontece no terreno. São mais elaborações teóricas, do que estudos de casos que nos podem ser úteis.

V.A.: Há também casos de alguns pesquisadores que depois de estudarem em um país africano, já se assumem como conhecedores de todo continente...

E.M.: Nós conhecemos muito bem aqueles que estudavam a situação dos Camarões no tempo do Ahmadou Ahidjo, tido como o especialista dos Camarões; não é nada mais nada menos que a continuação das práticas da etnologia colonial. Basta alguém estudar determinada tribo, se transforma logo num especialista do continente africano, ou dos povos primitivos. O que precisamos é romper com estas práticas e introduzir as nossas problemáticas africanas. Isto deve ser feito, porque temos o caso da Índia, onde conseguiram romper com as práticas europeias. Hoje são os europeus que vão para Índia, com o fito de recuperar as abordagens indianas. Precisamos de seguir o mesmo percurso.

V.A.: Lembro do caso do angolano Viriato da Cruz, que teve aquele incidente com Mao Tsé Tung, por não concordar com o projeto chinês a se implantar em África. Como o senhor vê a presença chinesa em África, as pretensões mantêm-se ou haverá diferenças em termos de objetivos?

E.M.: Hoje o cenário é um pouco diferente, porque a China mudou de estratégia, optando por um modelo de capitalismo nacional. Penso que se tivéssemos romancistas capazes, teria sido muito interessante escrever uma História de utopia, sobre as relações entre a China e o continente africano, no século XV. Tentar criar um cenário em que tivesse sido a China a chegar em África, em detrimento dos europeus. Podia ser uma forma de nos ajudar a imaginar cenários para o futuro.

V.A.: Como o senhor vê o ensino da História de África, em países como França e Brasil? Sente que já tem havido alguma evolução neste domínio? 
E.M.: Sim, no caso concreto do Brasil, com a lei que obriga as escolas desde os primeiros anos até a universidade a ensinar a História de África, sendo o primeiro país fora de África a tomar esta medida. A questão que se pode colocar é: até que ponto os brasileiros têm conhecimentos suficientes para ensinarem História de África? Tendo consciência que há pouca gente com qualificação suficiente, é interessante que eles hoje estão à procura dos africanos para preencherem estas vagas. Foi assim que o Kabengele [Munanga] conseguiu e hoje já está reformado. Eles estão abertos a jovens do continente africano. Acho que há uma oportunidade para nossa juventude, se calhar por algum tempo determinado, se calhar, depois de se confrontar com o terreno brasileiro, depois regressar para o continente a fim de dar sequência as suas pesquisas. Pensamos que os países Europeus deviam ter iniciativas similares. Porque, por exemplo, no caso de França, que votou uma lei que classifica a escravatura como um crime contra a humanidade. Mas eles têm uma ideia de nação que difere muito da nossa e assim a África continua a ser muito marginalizada.

V.A.: Acha que a Europa poderia reverter essa marginalização dos africanos?

E.M.: Sim, creio que deviam criar formas de reconhecimento. Porque temos pelo menos dois problemas: em primeiro lugar, a deportação e a escravatura (que difere da simples deportação). Em segundo lugar, o colonialismo. Há ainda casos que aconteceram no período pós-independência, por exemplo, o caso da guerra dos Camarões, ou o caso das intervenções no Congo, depois em Angola, e há ainda o caso da Líbia. Neste caso, em concreto, os europeus mataram um chefe de Estado legitimo. São questões muito importantes, mas para que a Europa aceite a questão da recuperação dos danos causados ao continente africano é necessário que os africanos trabalhem de forma convincente, com provas bem elaboradas, para que consigamos recuperar alguma coisa neste sentido. 